
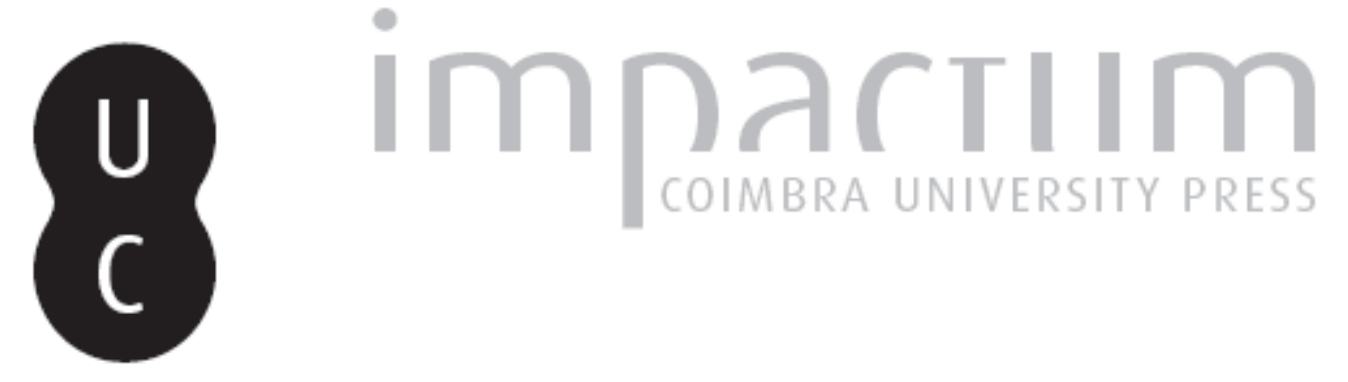

\title{
Sobre uma versão desconhecida de 0 Reino da Estupidez
}

Autor(es): $\quad$ Monteiro, Ofélia P.

Publicado por: Imprensa da Universidade de Coimbra

URL persistente:

URI:http://hdl.handle.net/10316.2/43912

DOI:

DOI:https://doi.org/10.14195/2183-8925_4-2_9

Accessed : $\quad$ 26-Apr-2023 14:45:42

A navegação consulta e descarregamento dos títulos inseridos nas Bibliotecas Digitais UC Digitalis, UC Pombalina e UC Impactum, pressupõem a aceitação plena e sem reservas dos Termos e Condições de Uso destas Bibliotecas Digitais, disponíveis em https://digitalis.uc.pt/pt-pt/termos.

Conforme exposto nos referidos Termos e Condições de Uso, o descarregamento de títulos de acesso restrito requer uma licença válida de autorização devendo o utilizador aceder ao(s) documento(s) a partir de um endereço de IP da instituição detentora da supramencionada licença.

Ao utilizador é apenas permitido o descarregamento para uso pessoal, pelo que o emprego do(s) título(s) descarregado(s) para outro fim, designadamente comercial, carece de autorização do respetivo autor ou editor da obra.

Na medida em que todas as obras da UC Digitalis se encontram protegidas pelo Código do Direito de Autor e Direitos Conexos e demais legislação aplicável, toda a cópia, parcial ou total, deste documento, nos casos em que é legalmente admitida, deverá conter ou fazer-se acompanhar por este aviso.

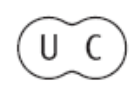




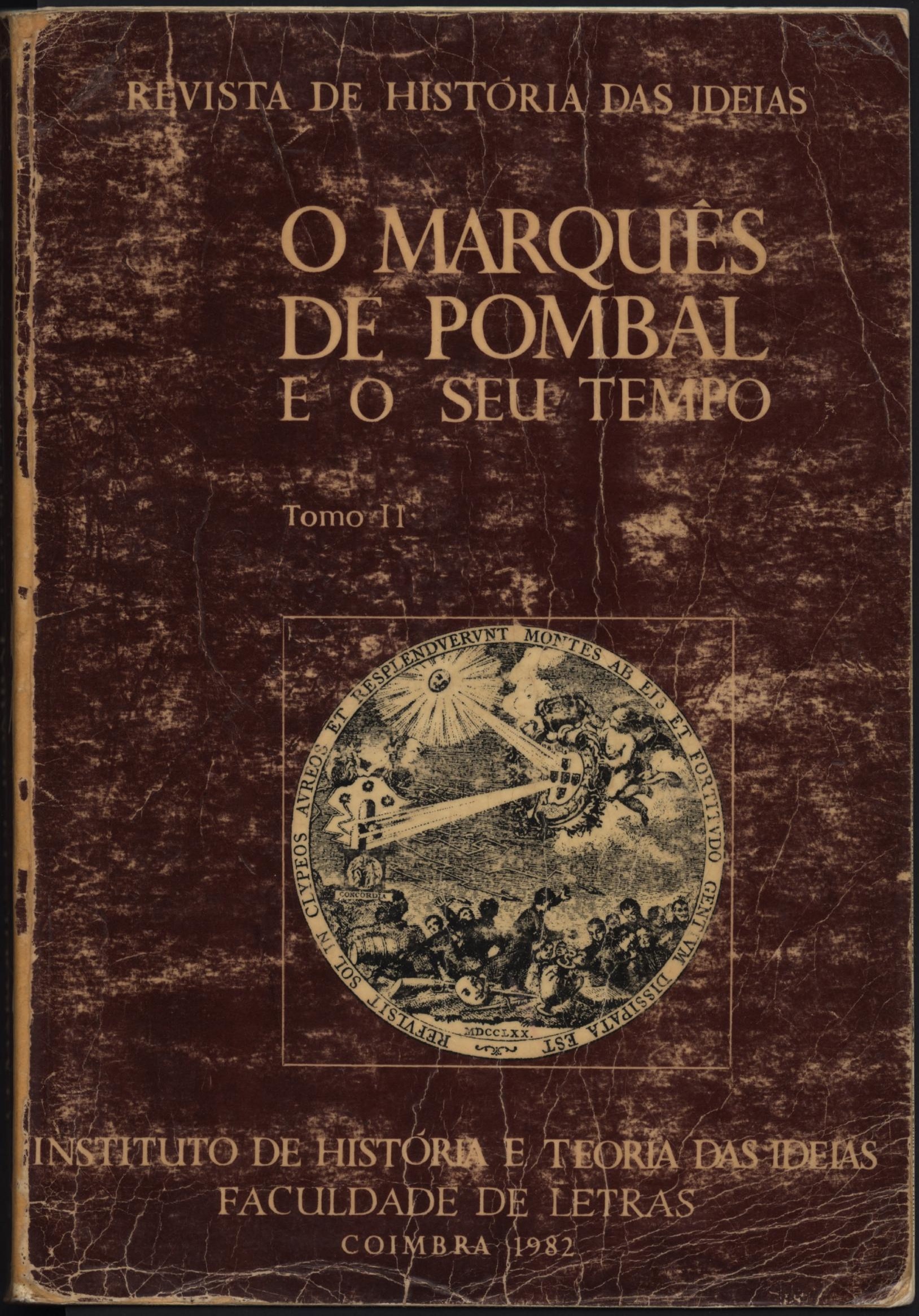


OFELIA P. MONTEIRO*

\section{SOBRE UMA VERSÃO DESCONHECIDA DE O REINO DA ESTUPIDEZ}

Têm estas páginas um objectivo modesto, já que o assunto de que versam carece ainda de ulteriores pesquisas: dar notícia da interessante versão manuscrita que se acha no espólio de Garrett, pertencente à Biblioteca Geral da Universidade de Coimbra $\left(^{1}\right)$, de $O$ Reino da Estupidez, o conhecido poema herói-cómico que a tradição mais comum atribui ao brasileiro Francisco de Melo Franco, associando-lhe, como colaborador na sua feitura ou na sua divulgação, José Bonifácio de Andrade e Silva, o "Patriarca da Independência» do Brasil.

Com toda a aparência dum texto na fase ainda de borrão, este manuscrito (n. 198 ), privado de qualquer indicação de autor, apresenta de facto divergências notórias quer em relação às numerosas cópias do poema que tive ocasião de compulsar, quer em relação às edições que dele se fizeram (a que julgo primeira data apenas de 1818 e foi realizada em Paris pelo Editor Bobée $\left({ }^{2}\right)$. Apesar de diversificadas entre si por algumas

* Faculdade de Letras da Universidade de Coimbra.

(1) Este espólio acha-se descriminado no Inventário do Espólio Literário de Garrett, organizado por Henrique de Campos Ferreira Lima (Coimbra, Publicações da Biblioteca Geral da Universidade, 1948).

$\left.{ }^{2}\right)$ Muitas cópias do poema se acham nas bibliotecas públicas e até particulares portuguesas. Cito algumas de que pude ter notícia: Biblioteca Geral da Universidade de Coimbra: ms. 1059 (miscelânea), ms. 1535 (misc.), ms. 2564, ms. 3016, ms. 3159 (misc.).

Biblioteca Nacional de Lisboa: F. G., Caixa 54, Doc. 39 (duas cópias). Luís de Albuquerque (a pp. 69-70 do trabalho indicado na n. 3) assinala 8 cópias mais.

Biblioteca Pública do Porto: ms. 571 (miscelânea, duas cópias); ms. 919 (miscelânea); ms. 754; ms. 1053.

Biblioteca Pública de Braga: ms. 370.

Biblioteca Pública de Evora: Cód. CXXX/2-10; cód. CXIV/1-25; cód. CXIV/1-26. 


\section{O Marquês de Pombal}

variantes, tais cópias e edições constituem uma "família» bastante homogénea: em todas o poema, precedido por um prólogo, desenvolve-se em quatro cantos que apresentam idêntica dimensão e idênticos episódios; daí que, na mais recente edição de $O$ Reino da Estupidez, tenha o seu organizador, o Prof. Luís de Albuquerque - que não conheceu o ms. 198 do espólio de Garrett, mas confrontou numerosas cópias e textos impressos do poema e pôde verificar a sua similitude-, adoptado o critério, aliás discutível, de apresentar uma versão "resultante» do seu trabalho de comparação $\left({ }^{3}\right)$. Ora, distinto dessa família que designarei globalmente por texto $A$, o ms. 198 do espólio de Garrett aparece-me até agora como exemplar único duma versão bem mais longa do poema, que aí atinge oito cantos, onde surgem episódios que nenhum dos outros textos apresenta e - como também sucede no Prólogo - passos novos ou profundamente alterados (designarei esta versão por texto $B$ ).

Não é para estranhar que se encontre um manuscrito do Reino da Estupidez no espólio de Garrett. Tanto ele como seu tio e educador, o Bispo de Angra, D. Frei Alexandre da Sagrada Família - cujos papéis, ricos em obras suas deixadas inéditas, foram desveladamente recolhidos pelo sobrinho, fazendo portanto parte do espólio - se dedicaram a coligir autógrafos ou cópias de obras alheias que andavam dispersas. E assim, por exemplo, que o ms. 199 desse rico fundo bibliográfico é constituído por poesias de José Anastácio da Cunha, reunidas em 1820 pelo jovem Garrett, e que o ms. 200 contém textos de Filinto Elísio, que o autor de Catão venerava como um mestre cujo estilo pretendia imitar; o ms. 207 é, por sua vez, uma "Colleç̧ão de Autographos de A. Ribeiro dos Santos, Almeno $e$ outros; com varias copias authenticas, portadora das indicações "Angra. Anno I (1821)" e duma Advertência, onde se lê, da mão de Garrett: «Esta colecção preciosa de manuscritos autógrafos e autênticos achei eu entre os de meu tio D. Fr. Alexandre da Sagrada Família, cujos restos pude alcançar (...)».

Sociedade Martins Sarmento (Guimarães): ms. B.G. 10-9-18.

Biblioteca particular dos Ex. ${ }^{\text {mos }}$ Senhores D. Beatriz Vizeu Pinheiro dos Santos e Henrique Jorge dos Santos.

Sobre as edições do Reino da Estupidez, vejam-se as indicações fornecidas por Luís de Albuquerque, a p. 69 do trabalho citado na n. 3. Assinalo que da edição feita em Hamburgo, em 1820, existe um exemplar na BGUC, integrado na miscelânea 3159 , constituída quase só por manuscritos.

$\left(^{3}\right)$ V. Luís de Albuquerque, «O Reino da Estupidez» e a reforma pombalina, Coimbra, Atlântida, Col. Textos Vértice / Cultura Portuguesa, 1975, pp. 69, 73 . 
Daqui resulta, porém, ser duvidoso avaliar se a presença do manuscrito do Reino da Estupidez no espólio se deverá a diligências pessoais de Garrett ou à circunstância de o ter simplesmente encontrado entre os papéis de seu Tio, pertencente à geração do seu autor, tenha ele sido Francisco de Melo Franco ou outrem.

Acrescente-se que quer com o perfil intelectual do Bispo de Angra, quer com o do jovem Garrett, condiz perfeitamente 0 interesse por esse poema herói-cómico, detractor do Portugal freirático e ignorante que, sacudido pelas medidas pombalinas - entre as quais a reforma da Universidade -, procurou recompor-se do abalo após a queda do Ministro, como em Coimbra se tornou tão visível. D. Frei Alexandre da Sagrada Família (1737-1818) foi, como procurei demonstrar em estudo publicado em $1974\left({ }^{4}\right)$, um representante paradigmático da articulação dum catolicismo austero e exigente com uma cultura moderna e crítica, pelo que se tornou um censor candente da Nação beata, devassa, inculta e socialmente desequilibrada do seu tempo. O jovem Garrett, caudilho dos estudantes liberais na Lusa Atenas, aí apanhou, como ele próprio disse, uma «indigestão de publicistas» $\left({ }^{5}\right)$ que $o$ ajudaram a almejar profundas reformas das estruturas e das mentalidades portuguesas. Daí que em tio e sobrinho, afastados, é certo, em matéria de fé e de programas políticos, se encontre um lamento comum pela nossa estagnação intelectual propiciadora do obscurantismo em todas as suas maléficas consequências. Numa epístola enviada a Almeno - o seu amigo Fr. José do Coração de Jesus -, D. Frei Alexandre lamenta, por exemplo, que os Portugueses se tenham transformado em "mimosos sibaritas» que, "adormecidos pela Deusa Preguiça», ostentam todavia uma "ignorância orgulhosa» que não deixa impune

(4) V. Ofélia M. Caldas Paiva Monteiro, D. Frei Alexandre da Sagrada Familia. A sua espiritualidade e a sua poética, Coimbra, 'Acta Universitatis Conimbrigensis', 1974.

$\left(^{5}\right)$ Mérope, prefácio (1841): «(...) depois tomei uma indigestão de Filangieri e de todos os publicistas que então eram moda em Coimbra» (in Obras Completas de Almeida Gärrett, ed. organizada por T. Braga, Lisboa, Empresa da História de Portugal, 1914, vol. I, p. 588). Sobre o perfil ideológico do jovem Garrett, v.: Augusto da Costa Dias, $O$ jovem Garrett. Esboço de ensaio sobre um grande vulto ignorado da filosofia portuguesa das Luzes, introd. a O Roubo das Sabinas de Garrett (2.a ed., Lisboa, Editorial Estampa, 1979); Ofélia M. Caldas Paiva Monteiro, A formação de Almeida Garrett. Experiência e criação, vol. I, Coimbra, Centro de Estudos Românicos, 1971. 
quem ousar dizer-lhe "que as luzes lhe falecem» ( $\left.{ }^{\circ}\right)$; nada de estranhar é, pois, que o Prelado admirasse o Marquês de Pombal, que considerava «iluminadíssimo» $\left({ }^{7}\right)$. Do jovem Garrett poderiam multiplicar-se citações demonstrativas do vivo descontentamento que lhe causou a decadência intelectual portuguesa, bem testemunhada na universidade coimbrã que conheceu. Valha por todas este parágrafo inserto numa das suas primeiras publicações, o folheto com que, em 1821, recém-formado em Leis, celebrou o primeiro aniversário do 24 de Agosto, mostrando a urgência nacional dum movimento regenerador:

«Passarei em silêncio a miserável decadência da Universidade de Coimbra; a ignorância de um grande número de seus mestres, a pedanteria deles, o espírito de partido que impede os progressos das ciências, e mil outras vergonhosas misérias que sofre um tão antigo e respeitável corpo literário» $\left({ }^{8}\right)$.

Não sei por enquanto dizer, porém, o que representa ao certo o ms. 198 do espólio. Tratando-se dum borrão, como provam as numerosas rasuras, acrescentos à margem e versos ainda toscos que o texto apresenta, ele será provavelmente uma versão anterior a $A$, resultante, esta, de correcções e largos cortes, exigidos talvez pela divulgação clandestina a que foi votada. Terão sido amputados do texto passos que permitiriam facilmente a identificação do autor? Voltarei mais adiante ao assunto; mas fique desde já apontado que $B$ e $A-$ a versão reduzida - mostram curiosamente, por vezes, bem distintos matizes ideológicos.

Passemos à apresentação do conteúdo do ms. 198, comparando-o sucintamente com a versão $A$, acessível aos leitores através da já referida edição do poema organizada por Luís de Albuquerque, que utilizarei em citações. Ao alto da sua primeira página, depois de uma folha de rosto onde se lê

( $\left.{ }^{\circ}\right)$ Expressões contidas na ode manuscrita $A$ Almeno (Fr. José do Coração de Jesus), que se encontra no Espólio de Garrett (ms. 195-II, 3. ${ }^{\circ}$ vol., n. ${ }^{\circ} 3$, pp. 107-110).

(') V. Ofélia Paiva Monteiro, D. Frei Alexandre da Sagrada Familia (...), pp. 11 (nota 29), 93, 144.

(8) O Dia Vinte e Quatro de Agosto, in Obras Completas de Almeida Garrett, ed. cit., vol. II, p. 512. 
apenas Estupidez, apresenta ele o título Reino da Estupidez, seguido das indicações Poema e Coimbra, no ano de $1785\left(^{\circ}\right)$.

Logo no Prólogo que, como na versão $A$, identifica o destinatário primeiro da obra com "esses que compõem a Universidaden, alguns passos novos oferecem interessantes achegas para a definição do perfil intelectual do Autor. Assim, a alusão aos vivos «desprezos» que sobretudo nos conventos recolherá o poema, dando em ambas as versões azo ao Autor para afirmar o seu respeito pelos «santos fundadores» das Ordens, que desejara ver imitados nos seus membros hodiernos, infelizmente degradados, salvo escassas excepções, numa vida dissoluta, só na versão $B$, mais radicalmente anti-clerical, adquire matizes que revelam associar-se à censura do relaxamento dos frades o desejo de diminuição da população monacal: se ela se reduzisse às vocações autênticas, não chegaria, alvitra o Autor, a atingir em todo o País «muitas dúzias», o que permitiria haver "mais pão para os que o ganham com suores industriosos, ou com as suas vigílias».

Ao referirem pouco depois o mísero saldo que os estudantes retiram da sua passagem por Coimbra, tanto $A$ como $B$ concentram a sua atenção nas faculdades jurídicas, lamentando que os legistas, «enfarinhados» em «quatro petas» de Direito Romano, ignorem o Direito Pátrio, o Direito Público, a Política, o Comércio - ou seja, tudo quanto podereria tornar-se «útil»-, e que os Canonistas se embruteçam com tanto Direito de Graciano enfiado na cabeça sem crítica nem método, sendo por isso levados a «engolirem» textos verdadeiros a par

(') Algumas cópias do poema ostentam a data de 1784. Assim, o ms. 2564 da BGUC tem no rosto as indicações seguintes: Reino da Estupidez / Poema heroico-comico. / Primr a edição / Dada à luz por *** | / Em Coimbra em Dezembro / 1784. (Tratar-se-ia duma cópia destinada a ser impressa? Não tenho notícia, porém, de nenhuma edição do poema feita no século XVIII). Também mencionam a data de 1784, pelo menos, uma das cópias do Reino da Estupidez integrada na miscelânea 571 da B. Pública do Porto e uma das incluídas no documento 39 (FG, Caixa 54) da B. Nacional de Lisboa.

Outras cópias indicam a data de 1785. Assim, por exemplo, o Cód. CXXX/2-10 da B. Pública de Evora, que contém as indicações seguintes: Poema intitulado / O Reyno da Estupidez / Composto / Por Fabricio Claudio Lucrecio / Sacio da Academia dos Observadores / | Edicçam correcta, e consideravelmente aumentada (...) / Parnazo | / Na officina das Musas: no anno de / 1785 / Com todas as Licenças Poeticas. Também por «edição correcta e consideravelmente aumentada» se dá a cópia do poema integrada na miscelânea 1535 da BGUC. Tanto num caso, como noutro, as cópias não se afastam, todavia, do texto $\mathrm{A}$. 
de apócrifos e a darem «a torto e a direito» poderes aos Papas que lhes não competem, "esbulhando" os Reis dos que a Monarquia lhes confere. Só, porém, na versão $B$ se acrescenta:

«(...) pelo contrário, os que vêm com presunções de poderem fazer um Comentário sobre as Ordenações do Reino e explicar toda a colecção de Harduino $\left({ }^{10}\right)$, por falta de ter entrado nos mistérios da profunda filosofia, ignorando os direitos da humanidade, fazem de cada vassalo um escravo, um forçado da galé, e de cada Rei um déspota; por outra parte, ignorando os direitos sólidos da Igreja, fazem escrava a Esposa de Cristo, e confundem o Bago com o Ceptro, tiram os marcos das duas Potestades, e quando protestam que as querem distinguir, as misturam mais, convertendo o principal em acessório.»

Quem apenas tiver lido a versão $A$ ficará por conseguinte convencido de que o seu Autor, bem a par da questão, candente na época, das relações entre os poderes da Igreja e do Estado, penderia para posições regalistas, preponderantes no pombalismo, já que aí se menciona apenas como um mal que aos Papas se concedam direitos indevidos, enquanto aos Reis se retiram outros que lhes competem. Com o vivo ataque, contido no Reino da Estupidez, ao Reitor D. José Francisco Miguel António de Mendonça - que após a queda do Marquês viera substituir o célebre D. Francisco de Lemos - condiria esse "regalismo» do Autor, já que o Principal Mendonça parecia, na matéria. de orientações mais eclécticas: a ele se devera, por exemplo, a proposta de substituir o compêndio de Instituicões Eclesiásticas de Febrónio, em uso - cuias doutrinas tinham servido os seguidores do despotismo iluminado e do regalismo aue o acompanhou -, pelas Instituicões de Jurisprudência Eclesiástica do professor austríaco Joseph Riegger, mais moderado neste campo, como era compreensivel num súbdito do império de Maria Teresa (11)

Se verificamos assim, desde o Prólogo, aue as vercões $A$ e $B$ nos dão do seu Autor matizes diferenciados, a idêntico

$\left(^{10}\right)$ jesuíta francês Jean Hardouin (1645-1729), bibliotecário e professor de teologia positiva no Colégio «Louis, le Grand», recebeu em 1687 a incumbência da publicação dos Acta Conciliorum et epistolae decretales ac constitutiones Summorum Pontificum, colecção que atingiu onze vols. e ficou terminada em 1715 .

(11) V. José Esteves Pereira, António Ribeiro dos Santos. O pensamento filosófico-politico (dissertação de Doutoramento policopiada). Coimbra, 1980, p. 17. 
resultado conduz o contacto com o texto do Poema em si. Acrescentos significativos se podem logo assinalar em $B$ nas sequências iniciais prescritas pelos cânones do poema heróico ou do herói-cómico, que o parodia: se a proposição é a mesma de $A$ - cantar a Estupidez que, «distante da Europa desterrada, / Na Lusitânia vem fundar seu Reino" - a invocação à Musa, pedindo auxílio, só em $B$ se acompanha duma outra, condizente com $o$ anti-clericalismo que tão intensamente se exprime no poema conjugado com a viva exaltação da autêntica religiosidade:

«Famoso Erasmo, que a atrevida pena

Mandar ousaste pesquisar os passos

Que na Europa outro tempo, altiva e livre,

A Estupidez soltava sem contraste,

Sustenta agora a débil pena minha,

Que o que a Musa ditar, escrever possa.»

A esta ousada invocação dum Erasmo tutelar (lembre-se que era autor do Elogio da Loucura) sempre só em $B$ se anexa uma dedicatória a Pope, esclarecedora dedicatória, pois sendo ele o autor de The Dunciad, poema satírico onde se "finge" a entronização da Estupidez na Grã-Bretanha, fica pelo próprio Autor sugerida a relação intertextual em que está com a obra inglesa $O$ Reino da Estupidez, como logo concluíram, aliás, os seus apologistas e detractores coevos. Eis o texto:

«Divino Pope, que os plautinos risos

Mais salgados tornaste, ao laureado

Da cabeça tiraste a não devida

Rama ilustre e sagrada: a ti dedico

Este frágil tributo, que a verdade

Arranca do meu peito lastimado.» ( ${ }^{12}$ )

(12) Ms. 198, C. I, vv. 18-23. O «laureado» a quem se refere o passo é o dramaturgo inglês Colley Cibber, «herói» do poema satírico de Pope na sua versão definitiva (1744). Um poeta menor francês, Charles Palissot (1730-1814), publicou em 1764 um poema satírio (onde troça dos «filósofos») com o título La Dunciade, largamente inspirado no de Pope. Alguns leitores coevos do Reino da Estupidez reúnem ao nome de Pope o de Palissot, como inspiradores do seu escondido autor: assim faz, por exemplo, o autor desconhecido do poema satírico em 7 cantos, $O$ Zello (ms. n..$^{\circ} 655$ da Biblioteca da Academia das Ciências de Lisboa, pp. $8 \mathrm{~A}$ e $17 \mathrm{~A}$ ). Sobre as relaçöes do Reino da Estupidez com The Dunciad, v. Luís de Albuquerque, op. cit., pp. 63-67. 
Inicia-se depois a narração. $O$ seu esquema diegético, idêntico ao da versão $A$, leva-nos do voto feito pela monstruosa deusa Estupidez de restaurar na Europa o seu antigo reino, perdido por artes de Minerva, à apoteose que lhe é oferecida em Coimbra por lentes e estudantes da Universidade, depois de azares sofridos nas terras estrangeiras que percorreu. $B$, como já disse, inclui, porém, múltiplos episódios e comentários que $A$ não apresenta. Assim, a matéria contida no canto I de $A$ estende-se, em $B$, pelos cantos I, II e III, que nos oferecem pitorescos relatos do que à Estupidez e sua corte de nefandos numes - as Fúrias, o Fanatismo, a Hipocrisia, a Superstição - acontece sucessivamente em França (canto I), na Inglaterra (canto II) e nos países do norte Europeu (canto III) $\left({ }^{13}\right)$.

$\mathrm{Na}$ versão $A$ limita-se o narrador a apontar que em França o Fanatismo, despedaçado de «tristeza e rancor» por ver «reinar somente a Humanidade», tentou inutilmente difundir as suas máximas: os mais «sisudos» respondem-lhe com «riso e mofa» e o "povo» apupa-o pelas ruas como se fosse um cão danado. Igual sorte - diz ainda $A$ - coube à Superstição e à Hipocrisia, pois em tal país, donde a Estupidez acaba por fugir com os seus acólitos vomitando pragas,

«Reinam a seu pesar a singeleza

Nos costumes, candura e sã verdade.» ( $\left.{ }^{14}\right)$

Bem diversa deste elogio sem reservas é a mensagem do canto I de $B$. Também aqui a Estupidez resolve, depois do sucedido aos seus comparsas, abandonar a França, maldizendo-a; fá-lo por ter concluído, porém, que a «gálica nação, ligeira e fofa» the não permitiria estabelecer um reino sólido:

«A mesma ligeireza desta gente,

Diversa de algum dia, me é contrária.»

Faria vacilar em breves dias

0 meu trono, se erguê-lo conseguísseis.

Mudar-lhe o génio fora hoje impossível.

Neste povo a verdade, ou a mentira,

Não podem ter seguro acolhimento.

0 interesse, a paixão, a seu capricho

Dispõem do afecto e dos juízos todos.

Busquemos outros ares, outros génios

Mais tenazes do que uma vez tomarem.» $\left({ }^{15}\right)$

(23) $O$ canto I de $A$ tem 177 vv.; em $B$, o c. I apresenta 263 vv.; o c. II, 228 vv.; o c. III, 215 vv.

(i4) Texto $A$ (ed. Albuquerque), p. 80. (Actualizei a grafia).

(is) Ms. 198 , c. I, vv. 250-260. 
Uma atitude irónica parece subjazer aos eventos imaginados para documentar a reacção dos Franceses às diligências dos auxiliadores da Estupidez. O Fanatismo é vítima do mesmo descrédito mofador de que dá conta a versão $A$. Do acontecido à Hipocrisia e à Superstição faz-se-nos, porém, um retrato bem mais longo, que o narrador entretece com comentários ambíguos cujo saldo parece ser a crítica da libertinagem dos costumes franceses e de certos paradoxos do "filosofismo». Diz-se-nos de facto que, ao tentar ajudar com as suas artes o Fanatismo que se achava em maus lençóis, a Hipocrisia é descoberta pelos Franceses, que decidem levá-la à presença do «Descaramento nobre, que se adora / Por virtude moral da gente franca». A propósito, comenta o narrador, num aplauso que, pela ironia, redunda em sátira:

«As leis tomaram deste, rejeitadas

As leis antigas, que seguiam cegos

Os Clodoveus, os Carlos, os Luíses.

Os bigodes cortaram e as espadas

Que alagavam de sangue o leito sacro,

Se algum profano amor ali se encosta.

Oh bárbaros costumes! Já fugistes.

Pode a moça gentil ter peito brando;

Pode a Esposa, se quer, tomar um sene,

E purgar o Marido mansamente;

Entrar no toucador o Petit-maitre,

Levar na sege a dama sem receio

De que o Pai ou Marido tomem duelo.

Santa paz!» $\left({ }^{16}\right)$

Não chega, porém, a Hipocrisia a defrontar o Descaramento, pois os Franceses que a levam presa, apercebendo-se de que de longe a segue a sua amiga Superstição, a largam para se apossarem dessoutra Fúria que conduzem à Bastilha, dispostos a açoutarem-na; e ter-se-ia cumprido a sentença popular se Voltaire não tivesse acorrido proclamando a inconveniência do castigo, numa fala que não deixa de hamonizar-se com a tolerância céptica do "filósofo»:

$$
\text { "(...) Suspendam, }
$$

Se não querem que o mal deite raízes.

Não sabem que é pior cortar esta Hidra, Que mil cabeças de diverso aspecto

(10) Ms. 198 , c. I, vv. 148-160. O sene é uma droga purgativa, extraída da folha de algumas plantas. 
Seu venenoso sangue ressuscita?

Se os ânimos franceses se esquentarem, Vê-los-eis outra vez cristãos inteiros.

Deixem, deixem correr a triste velha.

Fugirá ela mesma de enfadada,

Não achando nos peitos agasalho.

Por questões teológicas não sofro

Que o sangue a terra tinja.» ( $\left.{ }^{17}\right)$

Assim escapa ao chicote a Superstição, que vai "olho atrás, olho avante», contar o sucedido às companheiras, cheia de medo ainda. A Hipocrisia resolve então vingar-se de tantos desaires, imaginando um modo subtil de intervenção: toma a forma dum insecto que pica as cabeças dos Franceses, inoculando-lhes um "suco de infernal virtude», pois tem o condão de transtornar a capacidade de visão e de avaliação. Fermentando nos intelectos, tal suco vem a formar uns embrióes parecidos com sua "mãe», que, uma vez maturados, "picam a casca» e saem, «como pintos", pelas ruas, infestando o ambiente. "Que mais faz» - dizia ela com gáudio, vendo-se assim tão multiplicada - «que o vício feio / A capa tome da virtude, ou que esta / Arremede do vício a vil figura»? Por efeito deste «refinado elixir» que os impregnou - comenta o narrador -é que os Franceses, incapazes de se auto-avaliarem, se jactam de estar o seu País isento de Hipocrisia, reinando ao invés "a Singeleza / dos costumes, candura e sã verdade» (note-se como em $A$ estes versos adquirem um significado bem outro); e aduzindo provas das consequências da poção, narra:

«Já da Academia o louro venerando Marmontel, Sonarat (sic) e vários outros

$\mathrm{Na}$ fronte cinge, como génios raros, Que noutro tempo reputados foram Indignos de varrer a grande sala.

Tal poeta se admira, que de raro

Só tem que as asas, às avessas postas, Quanto mais as baterem, mais se abatem.

Também Sorbona da infecção padece

Algum tanto; consente que se escrevam, Porque interesses tem a Nação franca, Duras teses, já por seus antepassados Nos reinícolas Lusos estranhadas. Já sem lástima se ouvem os gemidos

(i') Ms. 198 , c. I, vv. $172-183$. 
Da liberdade humana posta em ferros, Por que em baixela de ouro os Galos bebam As lágrimas do injusto cativeiro Do inocente Africano em zrilhões duros.» ( $\left.{ }^{18}\right)$

Já sabemos que, apesar destes factos lisonjeiros, a Estupidez resolve, porém, cansada e receosa da «ligeireza» dos Franceses, buscar país mais propício para o seu reino. Seguindo o esquema diegético comum a $A$, o canto II de $B$ transporta-

( $\left.{ }^{18}\right)$ Ms. 198, c. I, vv. 225-242. Marmontel (Jean-François) foi activo colaborador da Encyclopedie e autor de tragédias e de narrativas «filosóficas», de enire os quais são de salientar Bélisaire (1767) e Les Incas (1777). Da sua extensa obra (19 vols. na ed. levada a efeito em Paris, em 1818), são as suas Mémoires que permanecem hoje mais vivas. Tornou-se membro da Academia Francesa em 1763 e, em 1783, foi nomeado seu secretário perpétuo. Não consegui identificar Sonarat. Tratar-se-á do naturalista e viajante francès Pierre Sonnerat (1745-1814), que deixou vários relatos de viagens?

As referências críticas à Sorbonne parecem aludir à aceitação, por parte da Universidade de Paris, de posições favoráveis à escravatura negra, justificadas por interesses económicos. D. Frei Alexandre da Sagrada Família, autor duma dissertação Contra a Escravatura, que publiquei no estudo cit. na n. 4, escreve, retorquindo aos argumentos expendidos por um autor francês, que não consegui identificar ,a favor da legitimidade do tráfico de escravos negros:

«Cabe logo na alçada da Igreja esta matéria; e errou torpemente o Francês em negar-lhe o poder para decidir na questão presente. Com efeito ainda não temos sobre isto ũa definição da Igreja. Porém, deste silêncio, que se pode inferir a favor da escravidão? Que a Igreja a tem por legítima e que aprova a prática dela? Bem aviados estávamos se o que a Igreja não tem dito a seus Filhos, nunca mais o pudesse dizer; se o silêncio dos séculos precedentes fosse lei à Igreja actual, se tudo o que a Igreja não tem definido ilícito fosse por isso mesmo confessado por ela honesto e lícito.

Advertirei de caminho o achaque das penas francesas, as mais fáceis de se prostituírem e venderen. Enquanto esta Nação não achou interesse no comércio dos negros, trovejaram os juristas galicanos contra os nossos juristas reinícolas que defendiam este comércio que nos era quase privativo. Começaram os Franceses a gostar deste ramo de comércio e veio a fazer-se esse tráfego um manancial de riquezas para a sua Nação; e eis aí o mesmo Clero a defender o que os seus patriotas, ainda seculares, abominavam. Grande cautela deve haver na leitura das obras desta Nação, a quem o interesse faz tomar partido nas controvérsias doutrinais, em que só a verdade e a razão deviam arrastar os homens.

Ao ponto. Que razão sólida se poderá dar para que sejam necessariamente livres os gentios da América e não os de Âfrica? São estes menos homens? Somos nós menos racionais neste continente do que no outro?» (Apud Ofélia P. Monteiro, op. cit., p. 381). Faço notar que, entre nós, se deveram ao Marquês de Pombal leis que declaravam inteiramente livres os índios do Brasil e decretaram a extinção da escravatura na metrópole (alvarás de 2 de Abril de 1761 e 15 de Janeiro de 17.74). 
-nos por isso a terras britânicas, para nos dar em saborosos passos, que lhe são exclusivos, notícia do que aí acontece à Deusa e à sua corte, que atravessam a Mancha voando numa formação cerrada que desequilibra, com o forte bater das suas asas, o "balão fumoso» de Blanchard $\left({ }^{19}\right)$, que nesse momento pairava sobre as águas. $\mathrm{Na}$ versão $A$, já privada da engraçada referência ao célebre aeronauta francês, diz-se-nos sucintamente que, chegadas a Inglaterra, a Estupidez e as Fúrias «a toda a parte correm», tentando amotinar os espíritos. «Mas que importa» - observa aí o narrador, explicando o fracasso que as espera -

«se a ti, profundo Povo, Brilhantes aparências nunca iludem?

Se buscas, por entre a verdade e o falso, Manifesta divisa, e só descansas Quando das cousas tens a sã medula?» $\left({ }^{20}\right)$

Ora a versão $B$ está de novo longe de conter tão entur siástico louvor dessa Inglaterra que para muitos se tornara, no século XVIII, uma nação-modelo pelo seu sistema parlamentar e pelo seu culto da liberdade e da tolerância. Também no ms. 198 a Estupidez e os seus acólitos espiolham por toda a parte; tal inquérito destina-se, porém, a um "congresso", no qual, ouvidos os resultados das buscas, se alvitrará o melhor modo de proceder em tal país. Diversos pareceres são aí dados: a Raiva quer, sem demora, atear "crua guerra, / Nos bravos corações rancor funesto / Acendendo»; a Superstição mostra-lhe, porém, quão difícil se tornaria a empresa: os Ingleses, diz ela, adoram um nume - a "Glória da Nação" - , ao qual consagram "quanto emprendem (sic) sobre o vasto globo» e pelo qual suportam «ferros" bem pesados e "tributos incríveis». O Povo, explica ainda, anda de facto "embebedado co'a fantasma / Da liberdade» - o nome que, no seu engano, dá à "dura escravidão» em que se acha de "duzentos senhores", que não passam de "sanguessugas do povo, e mais da Corte $\left.{ }^{21}\right)$. Assim parece insinuar-se na versão $B$ do poema - onde os numes maléficos falam frequentemente pelo Autor - uma crítica desfavorável do sistema parlamentar, confirmada pela alusão, também pejorativa, que logo depois a Superstição faz ao «destro Cromwel», que com tais artes conseguira tornar

(10) Jean-Pierre Blanchard (1753-1809), aeronauta francês, foi o inventor do pára-quedas.

$\left.{ }^{20}\right)$ Ed. Albuquerque, c. I, p. 80.

(2) Ms. 198, c. II, vv. 48-65. 
«escravo» um povo de «tiranos / De seus reis naturais», quando na Grã-Bretanha reinava a «santa Hipocrisia». «Hoje» é, porém, diversa a mentalidade inglesa - observa ainda a Superstição; «toda a revelação é desprezada», reinando "desde Windsor até à vil taverna" uma "vaga incredulidade» que, a propósito de tudo, "mete à bulha» os manes de Locke. Esta notícia da voga atingida na Grã-Bretanha pelo grande patrono seiscentista da negação das ideias inatas, do empirismo, da tolerância e do parlamentarismo, que tanto êxito colheu na Europa do século XVIII, poderia ter sido de molde a fazer desesperar a Estupidez de qualquer triunfo em terras inglesas se as Fúrias lhe não trouxessem também indicações consoladoras. Uma delas lembra-lhe que a história britânica lhe augura bons trunfos: pois, para "dar gosto a um Rei tirano e fero", não tinham os ingleses deixado a "lei pura» de seus "maiores» por outra nascida "entre as pernas de Ana Bolena»? Os tempos modernos - continua a mesma Fúria - também apresentam aspectos auspiciosos para a Estupidez: os Ingleses têm um humor irascível que se traduz nos "murros com que a plebe as ventas pisa" por "disputas de nonada» em que até as mulheres participam e que se apagam na taberna com cerveja; se os contendores são nobres, é à pistola que se resolvem as questões de honra; "e o que a mão tem mais certa é mais honrado" - observa ironicamente. A voga do suicídio - «virtude inglesa" que "cada dia a razão confunde e abafa» - e as desumanidades da colonização levada a efeito por um povo tão "filósofo» são outras provas que a Fúria aduz para justificar as viabilidades de triunfo que vê na Inglaterra para a Estupidez:

«Não vimos lá na América há dous dias Fechar os olhos a filosofia,

Enquanto o Marte inglês nas fonte lança

Cadáveres dos seus e dos imigos,

Por que estes bebam águas odiosas

E a podridão peleje pelos Anglos?» ( ${ }^{22}$ )

«Em tal mata de feras» - conclui ela, depois desta referência ao emprego de semelhantes processos de guerra biológica - «quem impede / Que tenha a Estupidez império, mando? / Quem é capaz do mais será do menos».

Acatado este voto pelo Congresso, a Deusa marcha com os seus sobre Londres, sonhando com o poder. Cega ambição!

${ }^{(2)}$ Ms. 198, c. II, vv. 109-114. 
- comenta o narrador ironicamente; reinar só a Estupidez sobre o povo britânico, um povo «livre»?

-Os Defeitos e os Vícios nesta gente

Serão livres e iguais em todo o tempo». $\left({ }^{23}\right)$

E de facto, mal se divulga o projecto da Estupidez, todos, escandalizados com esse seu voto de reinar sozinha, se acendem em ira:

\section{«(...) em furor monta}

Calcando o chapéu mais, o triste Quacker;

O Episcopal fulmina mil censuras;

O Presbiteriano amaldiçoa,

Grita à Constituição o Parlamento.»

Os «espíritos fortes», por sua vez, vão em procissão ao túmulo «do grande Locke»,

\section{«(...) levando ũa relíquia}

Dos calções de Voltaire, não mui limpa,

De quando o Rei da Prússia lhe pôs medo.»( ${ }^{24}$ )

Do buraco aberto na terra do sepulcro por um ouriço cacheiro que lá se enfia, sai «ũa cobra pintada de mil cores», que a todos lambe, assobiando, até se recolher de novo no seu abrigo tumular. Grande é o contentamento geral: não reinará a Estupidez onde houver «serpentes/Prudentes, vivas, de olhos penetrantes" - concluem os "espíritos fortes", que logo ali celebram o episódio devorando um "pudim», regado por "cem botelhas».

Restabelecidas do pânico que estes sucessos lhes causam, as Fúrias prosseguem, todavia, o seu plano de ataque, ganhando para a sua causa o chefe da Oposição, Lord Gordon; a moção que ele apresenta no Parlamento é, porém, derrotada pela escassa maioria de três votos, facto que transtorna o siso do turbulento Fidalgo, levando-o a suscitar uma revolta da plebe, que o Ministério em breve aesfria» prendendo o

( $\left.{ }^{2}\right)$ Ms. 198 , c. II, vv. $134-135$.

(24) Ms. 198, c. II, vv. 148-150. Voltaire permaneceu na Prússia entre 1750 e 1753 , mantendo com Frederico II intensas relações que se foram progressivamente degradando, a ponto de ter o Rei mandado prender, em Frankfurt, Voltaire e sua sobrinha, M.m Denis, durante um mês. 
responsável $\left.{ }^{25}\right)$. «A incredulidade tem seguro o sólio/Sobre as testas inglesas», conclui o narrador, que ironicamente comenta:

\author{
«(...) Grande gente! \\ Profundo povo! Que invadir não pode \\ Nem mole Estupidez, nem a Fé pura. \\ Se terá razão ou alma, é duvidoso \\ Entre os sábios que mais se gabam disso; \\ Tanta alma como um cão, dizem diversos. \\ Argumentos não bastam, evidências, \\ Oh profunda Nação, pedes, desejas; \\ Brilhantes aparências não te iludem. \\ A divisa entre o falso e o verdadeiro \\ Não te mostra a razão, a fé descansas \\ Quando das cousas vês a sã medula.» $\left({ }^{28}\right)$
}

Como vemos, o contexto em que, na versão $B$, se enquadra a alusão à incapacidade para iludir que as «brilhantes aparências» têm na Inglaterra confere-lhe um sentido bem diverso do elogioso que possui na versão $A$ : parece ironizar-se sobre o apego às «evidências» da "profunda» Nação, apego que a conduz tanto a uma desconfiança dos «argumentos» da razão para buscar a "divisa entre o falso e o verdadeiro", quanto a um abandono da fé.

$O$ canto II termina, todavia, em $B$, com algumas notas que sublinham a inegável supremacia da Inglaterra setecentista: diz-nos o narrador que Minerva, assistindo à dura luta dos "seus» Ingleses com a Estupidez, desce à Terra a abençoá-los, anunciando-lhes uma protecção que lhes permitirá crescerem "nas boas artes» e nas "ciências". "Para a vida" -

( $\left.{ }^{25}\right)$ Ms. 198, c. II, vv. 169-189. Lord George Gordon (1751-1793) foi um grande agitador político. Membro do Parlamento desde 1774, tornou-se em 1779 o presidente da associação de Protestantes criada para obter a revogação de leis de 1778 que tinham favorecido os católicos. Organizou um meeting em Saint-George Fields e, à frente de 10.000 homens, apresentou uma petição nesse sentido à Câmara dos Comuns, de que resultaram graves tumultos, entre 29 de Maio e 9 de Junho de 1780 , que o Governo só dominou através duma forte resistência armada. Numerosas mortes, prisões e execuções tiveram então lugar. Lord Gordon foi encarcerado na Torre de Londres e compareceu, a 5 de Fev. de 1781, em tribunal público, acusado de alta traição. Libertado, continuou a entregar-se à agitação política. O autor do Reino da Estupidez, apresentando Lord Gordon como um louco que quase conseguiu recuperar para a Estupidez, na Inglaterra, o seu antigo trono, mostra-se um juiz severo do sectarismo religioso.

(2) Ms. 198, c. II, vv. 192-203. 
diz-lhes a Deusa - não faz falta a asã Teologia» que vive "escura» entre vós; "esta ciência não se usava em meu tempo, nem me importan... $\left({ }^{27}\right)$.

São estes augúrios - que, embora no registo herói-cómico, apontam, como vemos, para o difícil diálogo moderno entre a Ciência e a Fé - que levam a Estupidez, que deles tem notícia, a abandonar, desesperada, com os seus a Grã-Bretanha. $O$ canto III de $B$ dá-nos notícia dos azares que ainda a esperam nas terras setentrionais, para onde o bando se dirige depois de ouvir «um ronco (...) da Ursa enregelada» que é tomado por augúrio favorável. Se, uma vez mais, o texto se expande em episódios e lances que se acham ausentes da sequência final do canto I de $A$, onde é narrada ainda esta passagem da Estupidez pelo norte europeu, não apresenta, porém, divergências de perspectiva, como as que até aqui assinalei. Ambas as versões dizem que a Estupidez consegue numerosos adeptos nessas regiões frias $-B$ esclarece que ela andou por Copenhague, Estocolmo, S. Petersburgo, Dantzig, Hamburgo e outras cidades ainda - a ponto de suscitar novamente a inquietação de Minerva, que decide descer outra vez à Terra para insuflar ânimo aos seus adeptos. $B$ explica que a Deusa da Ciência se apavorara ao saber que a Estupidez, tendo verificado a impossibilidade de descobrir nessas paragens "um povo de bestas» que lhe professasse «os dogmas todos" e lhes prestasse culto público, resolvera "plantar colónia nova", nas terras frias, "ajuntando os diversos convertidos». Retemperados com o dicurso que Minerva lhes dirige, os povos do Norte oferecem tão dura batalha às coortes da Estupidez, que estas se vêem obrigadas a abandonar o campo, refugiando-se em "oculto lugar» onde só moram "as mornas sombras da tristonha noute». E aí que o Fanatismo consola a Estupidez do novo desaire sofrido, aconselhando-a a trocar os gelos setentrionais por "climas áridos que esquentem/Os miolos da gente» antes que as luzes lhe aclarem a razão $\left({ }^{28}\right)$. $\mathrm{E}$ assim - já definido, como vemos, o contraste geográfico e cultural entre o Norte e o "Meio-dia», que tanta fortuna fará no início do século XIX - vêm as Fúrias e a sua Deusa até às "amenas Espanhas», onde o Fanatismo garante ter amigos poderosos «nos tribunais, nos templos, nos palácios». Nos cantos IV e V de $B$ desenvolve-se a matéria que, em em $A$, se concentra no canto II - um painel do que da vida

( $\left.{ }^{27}\right)$ Ms. 198, c. II, vv. 213-218.

(2) Ms. 198 , c. III, vv. 195-211. 
portuguesa descobrem a Estupidez e os seus acólitos, até se decidirem a buscar Coimbra como lugar de eleição $\left({ }^{29}\right)$.

O canto IV é o mais longo do ms. 198. Como em $A$, diz-se-nos aí que o "bando infame» dos Numes, desce caladamente em Lisboa por uma fria noite de Inverno, depois de ter decidido preferir a nossa capital a Madrid. $A$ atribui genericamente ao Fanatismo a proposta de tal opção. Na versão $B$, é, porém, a Estupidez quem desaconselha por menos propícia a capital castelhana, inicialmente preferida pela maioria das Fúrias, conhecedoras de casos que provavam a voga da Deusa por terras de Espanha: algumas referem-se a Esquilache e ao motim popular que originou porque «as abas imensas dos sombreiros/Pretendeu cercear" ${ }^{\left({ }^{30}\right.}$ ); outras evocam "os trabalhos injustos» que sofrera Campomanes "porque os reinos estranhos despojando /De povo enriquecera as ermas serras" $\left({ }^{31}\right)$; contam ainda que

\author{
«(...) em Sevilha um Comissário \\ Do Santo Tribunal despedaçara \\ As figuras de gesso em que se estudam \\ As leis da simetria e do debuxo, \\ Condenando o pintor à ignorância \\ Por evitar-lhe as tentações da carne» ( $\left.{ }^{32}\right)$.
}

A Estupidez tem, porém, razões determinantes para temer que em Espanha, onde tantos amigos conta, não possa estabelecer-se firmemente; ali reina "um velho" que Fintis
«De muitos homens, de cidades várias,
Os costumes tem visto, e quanto pode
O melhor no seu Reino plantar cura.

$\left.{ }^{(20}\right)$ O canto II de $A$ possui 382 vv.; o canto IV de $B$ atinge 465 vv. e o canto V 258 vv.

${ }^{\left({ }^{30}\right)}$ Ms. 198, c. IV, vv. 13-16. O Marquês de Esquilache, siciliano, foi durante algum tempo primeiro ministro de Carlos III. O famoso motim a que o texto se refere teve lugar em Madrid a 23 de Março de 1766 e obrigou o Rei a destituir e expulsar de Espanha o seu colaborador, que reorganigara a Fazenda e o Exército e empreendera importantes reformas urbanas. Parece hoje sem fundamento a opinião dos que consideraram os Jesuitas os instigadores deste tumulto popular, que foi muito comentado nas cortes europeias.

${ }^{(1)}$ Ms. 198 , c. IV, vv. 16-19. O Conde de Campomanes (1723-1803), como fiscal e depois presidente do Real Conselho Supremo de Castela, desenvolveu, no reinado de Carlos III, importantes esforços de dinamização no campo cultural e económico.

$\left.{ }^{(22}\right)$ Ms. 198 , c. IV, vv. 20-25. Recordo que em 1780 se fundara em Lisboa a Academia do $\mathrm{Nu}$, onde se praticava a pintura e a escultura a partir de modelos vivos. 
Não é feliz nas armas; mas é sábio Nas artes da política e paz dourada Ao povo ibero dá melhor que Numa» $\left({ }^{33}\right)$.

Não é para estranhar que o autor do poema faça este elogio de Carlos III, cujo reinado (1759-1788) correspondeu em Espanha ao apogeu do despotismo iluminado.

Recebendo o parecer da Estupidez a aprovação de todos, decide-se que as Fúrias, chegando a Lisboa, se espalhem sorrateiramente pela cidade, de modo a sondarem o ambiente português. Em $B$, uma nova interpelação à Musa tem aqui lugar, de tanto auxílio carecer - diz o Poeta - a «embotada pena" para se tornar capaz de retratar as "feições negras" das tantas asneiras "que na imensa Lisboa se praticam» $\left.{ }^{84}\right) . \mathrm{Na}$ versão $A$, o painel da vida lisboeta é dado por relatos que a todo o bando da Estupidez fazem sucessivamente do que viram a Raiva, a Superstição e a Hipocrisia - relatos tão significativos que o Fanatismo conclui estar garantido em Portugal o êxito da empresa: não lhe seria difícil, diz ele, suscitar em Lisboa, naquele próprio instante, o mesmo «furioso e ardente zelo" que originara em Paris os massacres da noite de Saint-Barthélémy ou que animava os "duros» Castelhanos» a regarem de "indiano sangue» o México e o Perú ${ }^{35}$ ). Em $B$ toma-se contacto com a realidade lisboeta pela voz do narrador que segue as Fúrias no seu deambular pela Cidade. Parte das cenas evocadas são comuns à versão $A$. Assim um e outro textos contêm o episódio - bem denunciador da soberba fidalga e do servilismo com que a ela se curvavam os representantes da ordem - em que um galhardo cadete, filho dum Conde, rapta uma jovem, maltratando não só o pai da moca quando tenta defendê-la, mas também o Ministro que, a pedido do pobre velho, procura chamar o Fidalgo à razão; é esse ministro - só $B$ o identifica como "ministro do bairro» - que responde ao "Pai aflito»:

«Amigo, são fidalgos, tenho feito

$\mathrm{Da}$ minha parte o que fazer podia:

Para os pequenos só as leis têm força.» ( ${ }^{36}$ )

${ }^{(33)}$ Ms. 198, c. IV, vv. 44-49.

(34) Ms. 198 , c. IV, vv. 83-88.

$\left({ }^{35}\right)$ Ed. Albuquerque, c. II, p. 98 . Cf. ms. 198, c. IV, vv. 384-398.

( $\left.{ }^{36}\right)$ Ed. Albuquerque, c. II, p. 88. Cf. ms. 198, c. IV, vv. 146-147. O Prof. Luís de Albuquerque insere na sua edição, depois destes versos, um passo que figura numa das cópias da B.N. de Lisboa (FG, Caixa 54, 
A este caso, que, em $B$, uma Fúria logo anota, porque de tal quilate «não vira/Nas nações que se aviltam por hereges», outros dão um complemento esclarecedor: de noite e de dia, a capital sofre roubos sem conta, praticados sobretudo diz-se em ambas as versões - por uma quadrilha de marujos sem medo da ronda que, em vez de espadas, traz «espetos ferrugentos». $B$ vai, porém, mais longe nestes lamentáveis "croquis» da cidade: o mercador, sem clientela - lê-se aí -, todo o dia «enxota as moscas» do seu balcão; o contrabando faz-se descaradamente por toda a parte - mesmo no Paço hipocritamente acobertado pela alegação de que o lucro se aplica "para a Igreja»:

«Até de quem governa se dizia,

E foi verdade, que milhões mandara

Para França, a prover o enxoval todo

$\mathrm{Da}$ bela infanta que levou Espanha.

E o português artista, que chuchando

Ficou no dedo, em cima foi mandado

Acender os cotinhos à janela

E festejar com lágrimas de cera

O que chora a Nação com as dos olhos". $\left({ }^{37}\right)$

Uma e outra versões falam-nos depois, em passo extremamente pitoresco (narrado em $A$, com muitas variantes, pela Superstição), da beatice alvar que se pratica na Cidade, explorada pelos frades Capuchos (de entre os quais $B$ singulariza ainda os Arrábidos): mostra-se-nos uma cena de exorcismos praticados em mulheres histéricas que querem ser libertadas dos «espíritos» que as habitam ou que cessem as doenças que lhes atacam os filhos; assim pudesse o "santinho" que as atende, lê-se ironicamente em $B$,

\author{
«(...) suspender as chuvas \\ Quando estragam os pães e as tempestades \\ Que os baixéis pelas costas espedaçam, \\ Quando vaza a maré mandar que suba». $\left.{ }^{(38}\right)$
}

Doc. 39, n. $\left.^{\circ} 1\right)$. Esse passo, que também se não encontra no ms. 198 do espólio de Garrett, insiste na acusação da fidalguia e coloca na boca do pai da jovem um lamento pela falta que faz ao Reino o Marquês de Pombal, «porque ele era somente quem sabia / Desta raça abater o grande orgulho»; o Ministro, que o ouve, recomenda-lhe prudência: tais palavras podem custar-lhe a vida, pois que «estes nossos fidalgos portugueses / $E$ gente que não tem nem lei nem roque».

${ }^{\left({ }^{37}\right)}$ Ms. 198, c. IV, vv. 166-174.

(') Ms. 198, c. IV, vv. 238-241. 
Compensam as canseiras do "Fradinho» os bons presentes que recebe e que lhe valem - $\operatorname{diz}$ discretamente o texto $A$ - «ser entre os seus padres respeitado" $\left({ }^{30}\right)$. $B$ torna-se mais explícito: dos presuntos, paios e bom vinho que lhe são enviados, pouco "goza" ele, pois aplica-os em bajulações aos que podem facultar-lhe preponderâncias e confortos dúbios:
«(...) o mais lhe come o Padre da Província
Que já definidor o preconiza
No vindouro capítulo, ou das Freiras
Um bom confessionário lhe assegura.» $\left({ }^{40}\right)$

Como era diferente - conclui-se em ambas as versões - a Lisboa de há dez anos (ou seja, a Lisboa de Pombal)! Agora $\operatorname{diz} B$ em texto próximo de $A-$

«Tudo é já devoção, tudo são terços,

Romarias, novenas, vias sacras,

Em que sempre um marmanjo de voz grossa

Para as janelas lembra a caridade.» ( $\left.{ }^{41}\right)$

Completarse esta esclarecedora evocação da Lisboa fradesca, viciosa e marialva das últimas décadas do século XVIII com quadros (narrados em $\boldsymbol{A}$ pela Hipocrisia) do que podia ver-se no «Passeio Público, onde concorre/A mais luzida gente» da Corte. "Quatro sujeitos de figura séria» - quatro "ginjas», lô-se em $B$ - comentam acremente o aspecto de dois mancebos ridiculamente vestidos segundo a moda estrangeira. que eles presumem serem desses que tomariam por grave ofensa o serem chamados "portugueses". $O$ lamento que, a propósito, faz um dos quatro homens sisudos da "miserável $\mathrm{Na}$ ção" que entrega os seus tesouros a estranhos "por fitas, por fivelas, por volantes/ $\mathrm{E}$ mil quinquilharias desta casta» interrompe-se, tanto na versão $A$ como na $B$, pela chegada súbita dum "carrinho" donde sai, ajudado por quatro moços «membrudos» e "asseados», um "gordo Bispo», cuja guapa toilette o texto $B$ descreve com impiedosa minúcia:

«Vinha todo de seda azul ferrete,

Casaca curta, cabeleira loura;

ũa cruz dependia do pescoşo,

$\left({ }^{30}\right)$ Ed. Albuquerque, c. II, p. 93.

('0) Ms. 198 , c. IV, vv. 260-263.

('1) Ms. 198 , c. IV, vv. 266-269. 
De luzentes safiras cravejada, Cercada de brilhantes; nas fivelas

Topázios brancos sobre o negro gritam.

O majestoso anel cegava os olhos.

Nos pulsos a finíssima rendinha

De França os punhos forma; brancas luvas

As cabeludas mãos lhe disfarçavam». ${ }^{(2)}$.

Ambas as versões registam o comentário cheio de azedume com que o mesmo "severo censor» ("austero secular», diz-se em $A$ ) verbera o «Bispo petit-maittre», recordando os «tempos primitivos» da «santa religião», «em que o Pastor só diferia / Do seu rebanho pelas sãs virtudes»; e ambas ainda referem que a $\mathrm{Hi}$ pocrisia, pouco satisfeita com as palavras de crítica que pudera ouvir, vai durante a noite ao quarto onde o bispo dorme regaladamente para substituir os sonhos que o possuíam galantes assembleias onde se jogava whist e se tomava café por outros que lhe aconselhavam a prática, por mera prudência, duma caridade tartufa.

Em $A$ conclui-se com este episódio o painel da vida lisboeta. O Fanatismo, como já ficou dito, considera o nosso País propício ao estabelecimento do Reino da Estupidez, mas sugere que, para a apoteose da Deusa, melhor lugar do que Lisboa - onde se fundara havia anos uma "cousa chamada Academia» que, aliás, lhe não causava receio - seria ainda Coimbra, a cidade universitária onde a Estupidez sofrera uma banição tão cruenta $\left({ }^{43}\right)$. Os dois últimos cantos - III e IV - dessa versão consagrar-se-ão, pois, ao acolhimento da Deusa na Lusa Atenas ( $\left.{ }^{44}\right)$. Em $B$ não se esgota, porém, com o episódio do Bispo «petit-maître» a evocação da capital portuguesa. A própria Estupidez passeia - ela também - por Lisboa. Vai à Graça - o Convento da Graça de Eremitas de Santo Agostinho - onde encontra um "régio professor» de latim que só sabia traduzir "o Concílio e Breviário»; "Vede lá que poetas, que oradores / Preparam estas aulas!» - exclama ela em «caquinadas de rison contente, tanto mais que é informada de pulularem em Lisboa, por «lei nova» e "consulta da Censória Mesa», "fradescos professores» que tornavam em «subsídio da igno-

('2) Ms. 198 , c. IV, vv. $315-324$.

(') Ed. Albuquerque, c. II, pp. 98-99.

(") Os cantos III e IV da versão $A$, ed. Albuquerque, possuem, respectivamente, 312 e 321 versos. 
rância» o «subsídio literário» que recebiam $\left({ }^{45}\right)$. Segue depois para a Praça do Comércio, onde encontra muitas pessoas que atentamente liam «ũa folha volante» escrita em «linguagem de Turquia", cena que dá azo a que o Autor do poema se revele um dos que verberavam, pelas décadas finais de Setecentos, a linguagem inçada de estrangeirismos, provindos sobretudo do francês, que por moda se praticava. A Estupidez, espantada, conclui que o seu domínio em Portugal ultrapassava mesmo o que sonhara: os mestres da língua - "o Brito, o Lobo, o Freire, / o Macedo, o Vieira, inda o Bernardes" $\left({ }^{46}\right)$ - eram desprezados; «termos, frases e estilo galicano, / Inglês, flamengo, turco e doutras gentes» era o que se encontrava na Gazeta - a Gazeta de Lisboa -, se não até no púlpito, onde ela ouvira um «um Paulista mui gavado» pregar em linguagem própria do Castrioto "as grandezas de Deus e de seus Santos» ( $\left.{ }^{47}\right)$. Que a falassem os Fidalgos, não seria para admirar, pois - continua a Estupidez, fazendo um «jeu de mots» -

$$
\text { «(...) dissipados }
$$

Por graça de Pombal os Puritanos, Nem da língua ouvir querem a pureza».

(5) Ms. 198, c. IV, vv. 402-417. O «subsídio literário» fora o im. posto criado, por alvará de 10 de Novembro de 1772, para prover aos encargos financeiros ocasionados pelas reformas pedagógicas levadas a efeito por Pombal. A Mesa Censória competia, entre outras tarefas, a administração e a direç̧ão dos estudos das escolas menores do Reino. O seu Presidente e três dos seus deputados (de nomeação régia) contavam-se entre os membros da junta a quem competia arrecadar o rendimento do subsídio literário. Após a queda de Pombal, a reforma dos estudos menores que ele tinha empreendido, confiando-os em grande parte a leigos, sofreu alterações profundas: parte do ensino foi entregue a conventos de religiosos e muitos professores régios compulsivamente aposentados com metade do vencimento. V. Joaquim Ferreira Gomes, O Marquês de Pombal e as reformas do ensino, Coimbra, Almedina, 1982, p. 41.

$\left.{ }^{48}\right)$ Ms. 198 , c. IV, vv. 418-434. Brito deve ser Fr. Bernardo de Brito (1568-1617), o conhecido historiador alcobacense; Lobo, Francisco Rodrigues Lobo; Freire, Francisco José Freire, mais conhecido por Cândido Lusitano; Macedo será provavelmente Agostinho José da Costa Macedo (1745-1822), activo colaborador do Dicionário da Academia das Ciências.

("17) Ms. 198, c. IV, vv. 435-437. Ignoro qual o pregador a quem se referirá o autor do Reino da Estupidez. Félix António Castrioto foi redactor, a partir de 1778, da Gazeta de Lisboa. Grande admirador da França, empregou muitos galicismos, o que motivou censuras várias de Filinto (v. nas Obras Completas de Filinto publicadas em Paris, em 1817 , t. II, pp. 200, 225; t. III, pp. 189, 306). 
logo comentando com malévola ironia:

«E é bem justo que em tudo se distinga

$\mathrm{Da}$ gente popular a gente ilustre.» $\left.{ }^{48}\right)$

O final do canto contém uma cómica amostra da linguagem "galicada» da fidalguia, acompanhada de graves acusações a essa classe:

«Assim refusar pode a reprimenda

Se em vez de pão de ló quer pão de Espanha,

Por salsa pedir sossa ao cozinheiro,

Campanha por campina correr pode, (...)

Das finanças pedir adiantadas.

Massacro horrível tema o credor tolo

Que fiou, se pedir o seu dinheiro;

Privilégio é do rang da Fidalguia

Mal falar, mal pagar e mal viver.» $\left({ }^{49}\right)$

Contente com o que vê, a Estupidez convoca os seus acólitos para uma reunião onde confrontarão os resultados a que chegaram e progamarão o que deva fazer-se.

Assim se passa ao canto $\mathrm{V}$, que continua a dar-nos quadros, que $A$ não apresenta, da vida portuguesa de então. Congregado o seu bando em oculto e tranquilo lugar, a Estupidez, verificando a falta de algumas das mais "activas e fogosas" Fúrias - o Interesse, a Discórdia, a Raiva, o Medo, a Vingança, o Furor -, decide adiar o Conselho. Para ocupar entretanto o tempo, dirige-se a Palmela, onde vai visitar o Real Convento dos Freires da Ordem de Santiago. Acolhida com gáudio "os sinos repicaram / Abriram-se os registos do grande órgão, / E luminárias houve» -, pouco aí acha a Deusa que corrigir, porque «em verde observância se conserva / Santa madraçaria» entre a maioria dos freires; no convento encontra apenas dois mestres, de Latim e Moral, aliás inactivos, pois se alguém ali se «aplica» é à picaria

( $\left.{ }^{48}\right)$ Ms. 198 , c. IV, vv. 439-444. Puritanos foi designação epocal para os fidalgos pertencentes às grandes casas da nobreza de sangue, extremamente poderosas, cuja preponderância Pombal procurou abater.

(') Ms. 198 , c. IV, vv. $445-456$. 
«(...) por que em seu cavalo

Quando vai a Setúval, fazer possa

Muita flor, muita sécia, muita asneira.» $\left({ }^{50}\right)$

"Grande socorro" se prepara às Igrejas da Ordem na sua casa-mãe! - conclui o narrador ironicamente, logo acrescentando que, todavia, nas "Oposições», se algum freire se encontrasse entre os candidatos, sempre obteria a preferência:

"Que é privilégio justo; e os sábios Becas

A consciência salvam do Grão Mestre

Dando o barrete a Igreja ao candidato,

Bem que seja um selvagem, um desonesto,

Que se é conventual todo al é nada.» ( $\left.{ }^{51}\right)$

Regressa a Estupidez, depois de abençoar o Convento de Palmela, ao local da reunião que marcara com os seus acólitos. Escorrendo suor, de fatigadas, já ali se acham as Fúrias que faltavam. A Raiva explica as razões da demora: retivera-a a ela e às outras comparsas - um capítulo que decorrera no Carmo de Lisboa para eleição dum Provincial; todas tinham andado em roda-viva:

«Os Frades pelas celas uns dos outros Como doudos andavam remexendo As paixões dos vogais. Qual me agarrava, Empurrando-me contra os que temia Que afeiçoados fossem do amarelo. Outro o Medo arrastou pelos bigodes E o pôs à porta de um de quem julgava Quereria votar no Mestre Augusto. A Discórdia nos ares em bolandas Andava, sem saber dar-se a partido; Querendo cada qual parcialidade Encaixá-la no meio da contrária. 0 Padre Vencimento, recordando Quanto rende a capela dos Terceiros, Do Interesse pegou, que engrandecendo O corpo, um grão gigante parecia,

$\left({ }^{50}\right)$ Ms. 198 , c. V, vv. 50-96. Em Palmela se estabelecera, desde meados do séc. XV, a sede da ordem militar de Santiago, cujo primeiro mestre foi o infante D. João, filho de D. João I. A partir de D. João III, por breve do papa Júlio III, de 1551, passou o «mestrado» da ordem a caber ao Rei português.

("1) Ms. 198, c. V, vv. 97-102. 
E em folhas de papel representava 0 mosteiro de Beja e de Tentúgal.

Entretanto o Furor, mais a Vingança, Não paravam; que todos pelas ventas Furores sorvem e vinganças espirram. Eram poucas as Fúrias do Inferno Para tanto trabalho: facas, trancas, Navalhões e pistolas, machadinhas, Espetos, garfos, sachos, tudo serve Neste breve momento de demora. Por encurtar razões, enfim saiu Provincial um Frade por três anos. E lá foram com todos os Diabos Cantando em grave tom Te Deum laudamus.» ( ${ }^{52}$ )

Este relato traz à Estupidez mais motivos para crer que está chegado o momento de entrarem apoteoticamente em Lisboa: se alguns inimigos ainda contassem, ou virariam a casaca, ou ficariam a um canto "chorando o samba" - diz ela. Só quanto ao lugar da entronização hesita a Deusa, pois no seu espírito três podem disputar essa honra - o Castelo, a Ajuda e a Praça do Comércio. Muitos votos reúne o Castelo, sede da influência de Pina Manique (que, como se sabe, aí tinha instalado a Casa Pia e a Casa da Forca) - "o Manique» de cuias "grossas letras» se ri o narrador $\left({ }^{53}\right)$; outras Fúrias prefeririam, porém. a Ajuda, pois esse obséquio se devia "ao Senhor Arcebispo barregudo" $\left({ }^{54}\right)$; também muitas optam pela Praça do Comércio, desejando que o triunfo da Estupidez se fizesse no lugar onde "se adora" a estátua do rei seu inimigo. As hesitações são, porém, resolvidas pelo Fanatismo que, como em A, aconselha para a apoteose a cidade de Coimbra, aludindo não só à vingança que se deveria tirar dos maus tratos que a Estupidez aí sofrera, mas ainda à importância vital dessa cidade onde se preparava o "fermento" que "toda a massa corrompe da Nação». Sublinhemos também que, em $B$, a referência crítica à recém-criada Academia das Ciências de Lisboa isenta de comentários desagradáveis o Duque de Lafões, seu grande patrono. Diz o Fanatismo, na verdade, que sabe ter-se fundado anos atrás «ũa cousa chamada Academia/Que um sábio Duque

(52) Ms. 198 , c. V, vv. $138-167$.

(s) Ms. 198 , c. V, vv. $199-205$.

(\$4) Ms. 198, c. V, vv. 207-209. Na Ajuda existia um palácio, mandado construir por D. José. Aí se manteve, durante algum tempo, a residência patriarcal. 
aspira a fazer grande», acrescentando: «Porém que há-de fazer? O melhor falta: / E sem gente jamais se fará guerra» $\left({ }^{55}\right)$.

Aos cantos VI, VII e VIII de $B$ correspondem, portanto, os cantos III e IV de $A$, que contêm a narração dos acontecimentos que acompanham a entronização da Estupidez em Coimbra $\left.{ }^{58}\right)$. O canto VI - mais ou menos correspondente, apesar das numerosas variantes, ao canto III de $A$ - inicia-se com a descrição da cidade do Mondego, tão linda quanto, no seu interior, "imunda", "irregular», "mal calçada" e "sem comércio». Segue-se-lhe (só em $B$ ) uma evocação rápida da "paz» que - salvo por ocasião da fundação do Colégio das Artes por D. João III - a Estupidez tinha sempre gozado em Coimbra até ao momento do desterro que lhe impusera a reforma pombalina, a que o narrador consagra um entusiástico elogio:

«Mas do seio da longa escuridade Um clarão se acendeu tão luminoso, Que a figura mostrou, medonha e feia, Da mole Estupidez; e envergonhados $\mathrm{Da}$ vil escravidão, os Lusitanos Cuspindo-lhe na cara a desprezaram. Um sábio rei, que eterno ser devia, Como o nome será nos nossos fastos, A desterrou daqui, tapando a porta Com dous grossos volumes, obra-prima.» $\left({ }^{57}\right)$

Espalhada pela Fama na Cidade a notícia da vinda da Estupidez a recobrar o seu antigo prestígio, gera-se um enorme alvoroço (novamente pede o Poeta à Musa inspiração para ser capaz de evocar quanto se passa). Conversa-se alegremente sobre o caso; nos conventos celebra-se com iguarias uma nova tão auspiciosa: ao vinho e ao presunto mencionados por ambas as versões, $B$ acrescenta a pitoresca referência às "tostadinhas tetas» do "manjar branco» que, nas celas, os reveren-

(55) Ms. 198, c. V, vv. 228-235. Os primeiros estatutos da Academia foram aprovados em Dezembro de 1779. A primeira sessão teve lugar em 24 de Setembro de 1780, sob a presidência do Duque de Lafões que, até 1783 , sustentou financeiramente a agremiação.

${ }^{(56)}$ No ms. 198, os cantos VI, VII e VIII possuem, respectivamente, 390,232 e 280 versos. Cf. $n$. 44 .

${ }^{\left({ }^{87}\right)}$ Ms. 198, c. VI, vv. 38-47. O texto deve referir-se ao Compendio historico do Estado da Universidade de Coimbra (...), publicado em 1771, ou aos Estatutos da Universidade de Coimbra (...), publicados no ano imediato. 
dos saboreiam com «angélica» ${ }^{58}$ ); enfim, na Universidade, o Reitor convoca um «claustro pleno» para que seja alvitrado o que fazer. $A$ e $B$ registam o aspecto da Sala dos Capelos e os discursos que aí se ouvem - o do lente primaz de Teologia (que alguns manuscritos identificam como D. Carlos Maria de Figueiredo Pimentel, então também exercendo funções de Vice-Reitor) e, depois, o de Tirceu, nome sob o qual se alude, também segundo muitos manuscritos, a José Monteiro da Rocha, lente de Astronomia, um dos activos colaboradores do Marquês de Pombal na reforma da Universidade. $O$ mestre de Teologia rejubila com a notícia. 0 teor do seu discurso, em $B$, mantêm-se idêntico ao que apresenta em $A$, apenas acrescido de algumas referências pitorescas a historietas da crónica coimbrã, que mostravam o prestígio que sempre tinha a Estupidez gozado na Alma Mater; lembra, por exemplo, que

$$
\text { «(...) inda vivem }
$$

Recentes as memórias veneráveis

De um Cristóvão de Almeida que, elevado

A mitra, consultar mandou o Papa

Se podia no fim da Ave Maria

Dizer Jesus, contrária sendo a praxe

A cartilha do Padre Mestre Inácio.» ( ${ }^{50}$ )

O mestre de Teologia é um detractor da reforma pombalina e das novidades que impusera: a Geometria, em seu entender, ensina "proposições heréticas», a História Natural, a Astronomia, a Anatomia, a Química são disciplinas inúteis que (só na versão B) ele diz terem «implícito pacto co'o Diabo»; "grandes» mestres para o Lente eram os de antes da nerregada reforma. como esse professor de anatomia aue só praticava a sua ciência no carneiro esfolado que um criado lhe trazia em banteja de prata, que pousava numa mesa coberta de damasco.

Idêntico também em $A$ e $B$, apesar das variantes, é o discurso de Tirceu: esse mestre esclarecido admoesta os colegas

(8s) Ms. 198, c. VI, vv. 71-73. A angélica é o licor fabricado com a planta do mesmo nome, também conhecida por nardo. Aparece, por vezes, como sinónimo de jeropiga.

${ }^{(50)}$ Ms. 198 , c. VI, vv. 106-112. O texto deve referir-se a Cristóvão de Almeida Soares, que em 1771 era decano da Faculdade de Cânones e veio a tornar-se bispo de Pinhel. Foi ele quem presidiu, em Junho de 1768, ao júri perante o qual António Ribeiro dos Santos realizou o seu exame de bacharel e quem o apadrinhou, em 1771, no acto de Doutoramento solene. A nota a, aposta na margem da p. 217 do ms. 198, esclarece: $\alpha$ facto certo; e ele mesmo mostrou a carta a uns Frades, consultando-os sobre o grande ponto de Teologia». 
que, tendo mostrado adesão calorosa à reforma em 72 , se àprestam agora a receber a Estupidez como deidade tutelar; e acompanha as suas palavras com comovidas homenagens à memória de Pombal, que ele diz repousar junto de Deus - «blasfémia» que faz um dos lentes favoráveis à Estupidez - Bustoque $\operatorname{diz} A$, Bristock lê-se em $B$ - abanar reprovadoramente a cabeça e dar "três cuadas" $\left({ }^{80}\right)$.

Ante discursos de tão diversas orientação, o Reitor dissolve o claustro sem tomar decisões. $\operatorname{Em} A$ como em $B$, cabe ao Fanatismo, que em sonhos lhe fala sob a forma inocente dum gordo rapazinho, resolver-lhe a inquietação em que se encontra, inspirando-lhe a homenagem a prestar à Estupidez, cuja execução ele prepara, mal acorda dum sono reparador, redigindo um edital. Entretanto tinham continuado na cidade os sinais de gáudio pela chegada iminente da Deusa:

\section{«(...) Nos Colégios \\ Todos três, à porfia, se preparam \\ Exquisitas ( $\mathrm{sic}$ ) e várias iguarias \\ Aos rubicundos e vorazes Becas» ( ${ }^{61}$ )}

- lê-se em $B$, enquanto $A$ só menciona, sem os especificar, dois colégios ( $\left.{ }^{62}\right)$; e nos conventos confecciona-se, com igual azáfama, "cousa mais grossa» onde o dente se «atole»:

\section{«Alarga a corda o Franciscano, o Monge Desaperta a correia; contradanças}

$\left({ }^{80}\right)$ Texto A (ed. Albuquerque), c. III, p. 109; ms. 198, c. VI, vv. 255-257. Fr. João de N. Senhora da Graça Brestóque (ou Bustóque) é citado, como professor da Faculdade de Teologia, por Manuel Eduardo da Mota Veiga, a p. 382 do seu Esboço Historico-Litterario da Faculdade de Theologia da Universidade de Coimbra (Coimbra, Imprensa da Universidade, 1872). Alguns tinham-no por «fanático e tolo», como se lê em nota apensa a um dos ms. do Reino da Estupidez. Cf. ed. Albuquerque, p. 109, n. 88 , e p. 125 , n. 95 .

${ }^{\left({ }^{1}\right)}$ Ms. 198, c. VI, vv. 299-302. Os três grandes colégios universitários, possuidores de ricas livrarias, eram os de S. Pedro, S. Paulo e das Ordens Militares, que albergavam doutores e licenciados.

${ }^{(22}$ ) Lê-se no texto $A$ (ed. Albuquerque, p. 111): «Era já noite e nos Colégios ambos / Exquisitos manjares esperavam / Aos rubicundos e nutridos Becas». Porque foi esta a versão que circulou, julgaram os contemporâneos do poema que ele visava particularmente os membros dos Colégios de S. Pedro e de S. Paulo, tanto mais que ou a um ou a outro pertenciam as pessoas directamente visadas. A verificação de que não eram feitas críticas ao Colégio dos Militares contribuiu para que se julgasse ser autor do poema António Ribeiro dos Santos que a ele pertencia. V. infra, p. 246. 
O Loio marca, e na Sofia toda

Viva a Defunta, grita o bom Pimenta» $\left({ }^{63}\right)$.

- $\operatorname{diz} B$, que não isenta de críticas, como vemos, qualquer agremiação religiosa.

Como ficou já dito, aos cantos VII e VIII de $B$ corresponde o IV e último canto de $A$, onde se evoca a recepção e homenagem feitas à Estupidez em Coimbra. A versão $B$ não se afasta muito de $A$, apenas se mostrando mais rica em pormenores ou comparações. Assim sucede, logo no início do canto VII, quando uma longa comparação aproxima o alvoroço que agita a cidade após a afixação do edital daquele que se verifica numa nau que vê surgir, enfim, a «suspirada terra" após uma longa viagem cheia de perigos. Idêntica em ambas as versões é a referência severamente crítica à vida ociosa dos estudantes gasta em tabernas, no jogo e em amores venais, idêntico o lastimável cômputo que ambas fazem dos que trabalham seriamente:

"Oh gente cega, bruta e mal criada

Que tão soberba sois como ignorante!

Duvido se entre tantos se acham doze

Que o título mereçam de estudantes» ( $\left.{ }^{64}\right)$.

lê-se em $B$, num passo que só matiza com mais revoltado ardor o que em $A$ se diz também.

Chegada a hora de cumprir-se o que pelo edital se estabelecia, todos se precipitam - estudantes, frades, doutores para a parte baixa da cidade, de modo a irem receber a Estupidez «além da ponte». $B$, sempre mais rico em pormenores, relata pitorescamente:

«Já do bicho escolástico grão turba

Se tinha adiantado, desejosos

De ver primeiro que outros a Deidade.

E tal a pressa foi que em Quebra-Costas

Caindo alguns, enxovalhando a loba,

Rasgada a capa, as pernas esfoladas,

Houveram de ir à festa coxeando,

E mais tarde que os outros lá chegaram» $\left({ }^{85}\right)$.

() Ms. 198 , c. VI, vv. $310-313$. Não sei quem seja Pimenta.

(ब) Ms. 198, c. VII, vv. 51-54. Cf. ed. Albuquerque, p. 118. 
Quando se aproximam do convento franciscano $\left({ }^{86}\right)$, surge-lhes a Estupidez, transportada numa nuvem esmaltada de estrelas; vem sentada num trono decorado com figuras que evocam os fastos que conhecera em Coimbra e com as obras produzidas pelos Lentes «desse século dourado». $B$ regista o grotesco aspecto da Deusa:

«As redondas bochechas luzidias

Um pouco arreganhava num sorriso

Que o grande ajuntamento embasbacava.

A gordura escorria-lhe da testa,

$\mathrm{E}$ ao reflexo das luzes das estrelas

Em torno cintilava do semblante» $\left({ }^{87}\right)$.

A Estupidez, que parece bela mesmo assim aos olhos deslumbrados que a contemplam, não desce, porém, ao pálio que o Reitor e os Lentes tinham preparado para a receberem; limita-se a dar-lhes a bênção, maliciosamente adjectivada, em $A$ como em $B$, de "papal», e prossegue o seu caminho em direcção à cidade, seguida pela multidão. Eis o relato de $B$ (ausente em $A$ ):

«Em duas salas, passo compassado,

Vão a nuvem seguindo, que em chegando

A Portagem, a parte esquerda toma

Pela longa Calcada caminhando.

As janelas acode, corre as ruas,

De toda a qualidade imenso povo,

Com que atulhada a rua de Coruche

Difícil passo deu ao Reitor mesmo» ( ${ }^{68}$ ).

O objectivo da Estupidez é de facto o mosteiro de Santa Cruz, onde quer passar a noite, pelo que o Reitor da Universidade ordena que só no dia seguinte seja feita a homenagem da Alma Mater, logo designando os oradores da sessão: Pedroso e Bristock, assinala o texto $B\left({ }^{68}\right)$. Esta versão demora-se entretanto,

\footnotetext{
( $\left.{ }^{65}\right)$ Ms. 198, c. VII, vv. 84-91.

(e) Trata-se do convento, sito na zona de Santa Clara, onde se acha hoje instalada uma fábrica de lanifícios.

("i) Ms. 198, c. VII, vv. 109-114.

( $\left.{ }^{\infty 8}\right)$ Ms. 198, c. VII, vv. 146-153. A Calçada constitui hoje a Rua Ferreira Borges; a rua de Coruche corresponde à actual Rua Visconde da Luz.

${ }^{(0)}$ Ms. 198, c. VII, vv. 171-174. Pedroso deve ser provavelmente Manuel Pedroso de Lima, que regia a disciplina de Direito Natural. Cf. T. Braga, História da Universidade de Coimbra, vol. III, p. 254. Sobre Bristock, v. nota 60.
} 
bem mais que $A$, na narração dos festins com que os Crúzios celebram a presença da Deusa no seu mosteiro:

«Mil carícias lhe fazem, mil lisonjas, Dispensou-se oração, não há silêncio, Pois que o Padre Geral ordena a todos

Se esmere cada qual em festejá-la. (...)

Foguetes não faltaram, houve outeiro Em que as musas vadias, mandrionas, Da Estupidez cantaram os louvores Ao som dos instrumentos afinados. Epigramas latinos se mandaram De diversos conventos por presente E um tratado de Súmulas prolixo A sua protectora dedicado. Veio a Ponte dos Asnos feita em doce» $\left({ }^{70}\right)$ (...)

Pelos outros conventos da cidade, aliás, também os frades celebram, "em função de barriga e de badalo", a vinda da Estupidez, escondendo hipocritamente - lê-se em $B-a$ inveja que lhes causara a manifesta preferência com que ela distinguira os Crúzios:

"Os tempos volvem, dizem, em que os Crúzios

Os galinhos serão da nossa Atenas,

Como algum dia, para ser ditoso,

Forçoso era dos Crúzios ser escravo;

Para o Reformador ter favorável,

Lograr os Padres, sendo confessado

De algum deles, e comungar devoto,

Rezar logo a estação em cruz os braços,

Beijar a terra, as lajes, os estrados;

Nem podia sem isso ir a Sandelgas

Doutor ou Estudante sem perigo:

Assim quem ser estúpido deseia

Procure ser dos Crúzios afilhado" $\left({ }^{71}\right)$.

Só no canto final, o VIII, insere o texto $B$ o relato da homenagem universitária à Estupidez, em parte inspirada nas cerimónias do Doutoramento solene. Aí se nos narra, como em

( $\left.{ }^{70}\right)$ Ms. 198 , c. VII, vv. $179-182$ e 203-211.

(i) Ms. 198, c. VII, vv. 185-197. Em Sandelgas, próximo de Coimbra, se estabeleceu em 1691 um convento de freiras franciscanas, hoje completamente em ruínas, onde se realizavam outeiros. 
$A$, os preparativos que todos fazem para irem condignamente buscar ao Mosteiro de Santa Cruz a gorda Deusa, que surge num andor formado pelos braços de quatro espadaúdos mestres do Colégio Novo $\left({ }^{72}\right)$. Despede-se da Estupidez o Prior do Convento. Os termos em que o faz, na versão $B$, redundam numa crua crítica ao espírito da congregação, acusada de relaxamento e de prática da usura (o que $A$ omite):

«Oh Deusa amável, diz, ampara e zela

Estes filhos que tanto te merecem,

Como a teu Nume devem. Por ti gozam

Deste honrado sossego, esta alegria,

Esta forte saúde, esta gordura,

Esta imensa riqueza que aumentamos

Com dinheiros a juro, em que se ganham

Dous por cento cada ano sem falência,

Tomando o juro a três e dando a cinco" $\left({ }^{73}\right)$.

Segue-se, como em $A$, a descrição do cortejo que conduz a Estupidez à Universidade e, depois de nova invocação do Poeta à Musa a pedir-lhe fogo idêntico ao que inspirou $O$ Hissope, a evocação da cerimónia que aí tem lugar. Colocada num trono decorado com figurações alegóricas - sob o assento vêem-se, aferrolhados, a Ciência, a Razão e o Desengano e (só em $B$ ) decoram o espaldar «a Arrogância e a Preguiça coroadas" - a Deusa ouve os discursos dos Lentes Bristock (Bustoque em $A$ ) e Pedroso. 0 primeiro advoga durante uma hora, em mau latim, a causa do ensino nessa língua, acusa (só em $B$ ) as ciências de profanarem a Teologia e exalta a "forma silozística» como método para achar a verdade $\left({ }^{74}\right)$; o segundo, responsável pela cadeira de Prima na Faculdade de Leis, traça, todo "inchado", a "grão genealogia» da Estupidez, passando depois ao elogio do Direito Romano $\left({ }^{75}\right)$. No fim de ambas as palestras, o Reitor jura por todos obediência e lealdade à Deusa, que coroa com um riquíssimo diadema. Seguem-se os sinais de apreço e vassalagem dos presentes. Um

$\left({ }^{12}\right)$ Ms. 198 , c. VIII, vv. 45-49. Por «Colégio Novo» era vulgarmente designado o Colégio de Santo Agostinho ou da Sapiência, que, no final do séc. XVI, fora criado pela Congregação de Santa Cruz afim de aí instalar os seus colegiais, retirando-os do Mosteiro. No edifício do "Colégio Novo» veio a instalar-se mais tarde o Colégio dos órfãos. As cerimónias do Doutoramento Solene começavam por um cortejo, onde se integravam os lentes de todas as Faculdades, que tinha por função conduzir o doutorando do Terreiro de Sansão à Universidade.

${ }^{\text {(3) }}$ Ms. 198, c. VIII, vv. 57-65.

("4) Ms. 198, c. VIII, vv. 152-165. Cf. ed. Albuquerque, p. 125.

$\left({ }^{75}\right)$ Ms. 198, c. VIII, vv. 166-181. Cf. ed. Albuquerque, p. 126. 
professor oferece-lhe a oração De Sapientia que lhe tinha granjeado a rápida ascensão à situação de Lente, outro uma análise do "parto septimestre»; um grupo de retóricos delega num deles, mestre Bezerra, o elogio das vantagens pedagógicas da «bela ciência» que praticavam $\left({ }^{78}\right.$ ); um fidalgo (o morgado de Sinde e Alpoins, José Correia de Melo e Brito d'Alvim Pinto) oferece à Deusa o seu poema épico Joaneida $\left({ }^{77}\right)$; uma «turba imensa» de estudantes vem trazer-lhe asuados frutos» da História Natural - uma «flor, um «bichinho», um «ninho de pardal», um "gafanhoto" -, um outro queixa-se-lhe de um colega que lhe "usurpara» a "glória" de ter feito com êxito «sete máquinas» aéreas $\left({ }^{78}\right)$. Grata por tantos sinais de apreço, aos estudantes naturalistas responde a Deusa no texto $B$, por uma forma um pouco mais malévola do que em $A$ :
«Amados filhos, (...)
Esse vosso cuidado me consola.
Esse disvelo (sic) de ajuntar cousinhas
Tão lindas como inúteis, digno emprego
E de almas, como as vossas, sensitivas.
Prossegui nesse estudo, eu vos prometo
A minha proteç̧ão em toda a vida» $\left({ }^{70}\right)$.

E ao queixoso retorque, consolando-o (em texto bastante diverso do apresentado por $A$ ):
«(...) Sinto deveras
Que tenhas essa causa de tristeza.
Mas consola-te. Ao ver-te dirão todos
Que máquinas só tu fazer podias.

${ }^{78}$ ) Ms. 198, c. VIII, vv. 196-216. Cf. ed. Albuquerque, pp. 127-128. João António Bezerra de Lima (1737-1812), segundo informações contidas no Dic. Bibliographico de Inocêncio Fr. da Silva (t. III), formou-se em Leis, em Coimbra, em 1768. Foi professor de gramática latina e, depois, de Retórica, no Colégio das Artes, onde recitou, em 1778, um Discurso sobre o uso da crítica, impresso na "Real Oficina» da Universidade; de 1773 data a publicação, levada a efeito pela mesma Imprensa, de Quatro Odes suas. Filinto Elísio troçava do seu talento poético (cf. Obras, Paris, 1817, t. IV, p. 296), que igualmente satirizaram outros contemporâneos. Cf. Luís de Albuquerque, op. cit., n. 98, p. 127.

${ }^{(77)}$ Também segundo o Dic. Bibl. (t. IV), este fidalgo foi sócio da Academia Litúrgica de Coimbra e correspondente, até 1798, da Academia das Ciências de Lisboa. A «Oficina» da Universidade publicara em 1782 a sua Joaneida, ou a Liberdade de Portugal, defendida pelo Senhor Rei D. João I.

$\left({ }^{78}\right)$ Ms. 198, c. VIII, vv. 232-239. Experiências de aerostação foram efectivamente levadas a efeito em Coimbra (cf. Simões de Castro, Memoria Historica da Faculdade de Filosofia, Coimbra, 1872, p. 181 e segs. Cf. ed. Albuquerque, c. IV, pp. 128-129.

${ }^{(7)}$ Ms. 198, c. VIII, vv. 240-246. Cf. ed. Albuquerque, p. 129. 


\section{O Marquês de Pombal}

0 gás te está saindo pelos olhos,

Bem se vê que a cabeça dele é cheia» $\left({ }^{80}\right)$.

Os Doutores vêm, enfim, em massa, mostrar o seu apreço à Estupidez, que brinca entretanto com os anéis da cabeleira do Morgado que sentara a seu lado, deixandoo receoso de ficar com a calvície descoberta. Diz o texto $B$ que os Lentes se prestam todos à vassalagem, a maioria «contentes», mas alguns "forçados» $\left({ }^{81}\right)$. As duas versões registam que a Deusa os recebe gratamente, ficando «assombrada», porém, ao ver a catadura do lente Trigoso:

«Não menos carregada que a dum touro

Que assopra e para trás a terra lança

Quando irado para investir se ensaia» ( $\left.{ }^{82}\right)$.

A cerimónia termina - terminando o poema também em ambas as versões - com a promessa formal que a Estupidez faz de continuar protegendo a Universidade e os seus membros:

«Eu gostosa vos lanço a minha bênção.

Prossezui, como sois, a ser bons filhos;

Que a mesma, que hoje sou, hei-de ser sempre» $\left({ }^{83}\right)$.

Concluída a evocação do conteúdo do manuscrito 198 numa comparação rápida com a versão $A$, representante do texto corrente de $O$ Reino da Estupidez, é possível, como vemos, enriquecer com mais alguns traços, não despiciendos, o perfil do seu autor implícito ( ${ }^{83}$ a $)$. Trata-se, como é óbvio, de um descontente com a "Viradeira", apresentada como um retrocesso particularmente sentido nos campos sócio-político e cultural. Defensor das «luzes» da Razão e desejoso duma instrução que, servindo-as, pudesse tornar-se útil ao País, o autor satiriza, como vimos, os sintomas que denunciavam no

( $\left.{ }^{\circ 0}\right)$ Ms. 198, c. VIII, vv. 247-252. Cf. ed. Albuquerque, p. 129.

(8) Ms. 198, c. VIII, v. 264.

(82) Ms. 198, c. VIII, vv. 268-270. Cf. ed. Albuquerque, p. 130. $O$ texto refere-se a Manuel Pais de Aragão Trigoso, doutor em Cânones. Ignoro que motivos levam o autor do Reino da Estupidez a evocá-lo por esta forma, que parece colocá-lo no número dos lentes que só «forçados» vão saudar a Estupidez.

${ }^{(85)}$ Ms. 198, c. VIII, vv. 278-280. Cf. ed. Albuquerque, p. 130.

(s) a) Chamo, com W. Booth (The Rhetoric of Fiction, University of Chicago Press, 1961, pp. 70-75), autor implícito à instância organizadora duma obra, ao efectivo «sujeito» da enunciação da narrativa. Veja-se, do mesmo autor, «Distance et point de vue. Essai de classification», in Poétique du récit, Paris, Seuil, 1977. 
espaço português a perda do ímpeto renovador que Pombal tinha imposto, focando-os com mais insistência em Coimbra, lugar dessa Universidade que o ministro de D. José tinha querido tornar o centro de formação duma juventude "esclarecida», capaz de modificar a mentalidade nacional.

Muitos dos males cujo ressurgimento detecta no ensino das várias faculdades "respondem" precisamente a pontos inovadores da reforma pombalina: recorde-se, por exemplo, como ri da desconfiança votada às ciências experimentais, tidas por potencialmente heréticas, como troça do apego ao Direito Romano, em desabono do Público ou do Pátrio, como mete a ridículo o gosto pela agudeza silogística, a teima na utilização do latim nas aulas universitárias ou os escrúpulos religiosos na prática da anatomia em cadáver humano. 0 "pombalismo" do autor implícito do ms. 198 não é, porém, tão cego que lhe feche os olhos para males assinaláveis em áreas do saber estreitamente ligadas às próprias sendas abertas pela reforma de 72. Lembro que ele nos mostra a Estupidez recebendo com agrado os presentes pueris de estudantes de Ciências da Natureza, depois de nos ter falado depreciativamente, no Prólogo, da "materialidade» da maioria dos mestres de tais disciplinas; ou que aí também se refere negativamente aos que, nas faculdades jurídicas, se aventuravam, seguindo as orientações pombalinas mas sem conhecimentos suficientes para tanto, em comentários às Ordenações do Reino ou à Colecção de Direito Canónico de Hardouin, chegando a conclusões que ele reputa nefastas: a confusão do «Bago com o Ceptro" ou a redução do "vassalo» a "escravo" dum rei-déspota. O Prólogo parece, aliás, genericamente insinuar - tanto na versão $A$ como na $B$ - que a reforma pombalina, em si cheia de potencialidades promissoras, se tornara quase nociva para a Universidade por não estar ela preparada para ser dinamicamente capaz de prosseguir nas sendas impostas. Julgo ser esse o sentido da imagem que serve ao Autor para de antemão responder aos que imaginava iriam logo acusar o seu pooma de "pouco verdadeiro", alegando que a Universidade estava "no seu auge» após a Reforma e que sátira tão violenta como a do Reino (...) só se explicaria como fruto dum espírito «maldizente por ofício» ou ignorante das remodelações de $\mathbf{7 2}$. Ouçamo-lo na apóstrofe que dirige ao próprio poema:

«Mas a esses pede a resolução deste problema. Achava-se um homem sepultado em profundo sono, alta e tenebrosa noute, sobre um rochedo cercado de mil despenhadeiros: compadecido outro homem daquele perigoso estado, chega a ele, desperta-o, 
convida-o que o siga para o tirar de tanto risco; mas dados poucos passos, morre o benfeitor. Fica o infeliz ainda em trevas, já acordado, já por entre os precipícios, e sem guia. Quando foi mais desgraçado este homem? Quando estava entregue ao letargo, ou, quando acordado, se viu só e em trevas?» ( $\left.{ }^{84}\right)$.

A imagem era pertinente. $\mathrm{Da}$ inércia que a breve trecho se seguiu à reforma pombalina - de certo modo favorecida até por ela (lembre-se a imposição do ensino por manuais que tiveram de ser traduzidos e adaptados de outros estrangeiros, ficando por largos anos em uso) - dão prova inequívoca os factos: basta evocar a urgência que sentiu D. Francisco Rafael de Castro, mal ascendeu ao Reitorado após a demissão do Principal Mendonça, de promover a confecção de compêndios por docentes de Coimbra e de melhorar, dum modo geral, o equipamento didáctico da Universidade ${ }^{85}$ ).

A envolver esta denúncia da degradação do espírito da reforma universitária de 72 nas mãos dos que a denegriam ou dos que a não sabiam executar, está no Reino da Estupidez a generalizada acusação da mentalidade retrógrada e da relaxada inoperância do País, particularmente assinaladas nas classes sociais preponderantes que, inquietadas por Pombal, levantavam aliviadamente a cabeça após a sua queda. A que mais cruel e mais constante sátira recebe é, como vimos, o Clero - sobretudo o clero regular - intimamente responsável do clima moral e intelectual da Nação dadas as tarefas de orientação religiosa e educativa que latamente lhe competiam. A nobreza recebe, contudo, acusações também duríssimas, como é notório no episódio do jovem fidalgo prepotente e

(\$) Cito o texto do ms. 198. Cf. ed. Albuquerque, pp. 74-75.

( $\left.{ }^{85}\right)$ decreto de nomeação do Principal Castro é de 3 de Dezembro de 1785 . José Esteves Pereira cita, a pp. 43-44 da sua dissertação de Doutoramento, António Ribeiro dos Santos. O pensamento filosófico-político (Coimbra, 1980), dois esclarecedores avisos régios, lidos na Congregação da Faculdade de Cânones realizada a 22 de Nov. de 1786, que acusavam a inércia da Universidade. "No espaço de catorze anos, com espanto das Universidades estrangeiras» - dizia-se num deles - não tinha a Universidade de Coimbra «produzido escrito algum» que fizesse ver os «progressos académicos», servindo-se «de livros adoptados quando já os podia ter próprios». Várias vozes detractoras do Reino da Estupidez sublinham que, se a Estupidez era senhora da Universidade após a queda de Pombal, tais males vinham do princípio mesmo da Reforma. Os compêndios permaneciam os mesmos, os mestres não tinham mudado - lembra, por exemplo, o autor duma Ode o. Fileno (BGUC, ms. 1327, p. 15), reportando-se às acusações feitas pelo poema herói-cómico . 
imoral que rapta uma jovem maltratando-lhe o pai e a auto ridade civil a quem ele recorre. Tais críticas, associadas ao lamento do marasmo que atingia a indústria e o comércio nacionais e ao louvor dos progressos ingleses nas «artes» e nas ciências, vêm harmonicamente integrar-se no "pombalismo" do autor implícito do poema: o Ministro de D. José tentara promover o surto da burguesia trabalhadora e perseguira os privilégios de que gozavam as instituições conventuais e grandes casas da nobreza de sangue, particularmente se ligadas à economia ultramarina ou ao ensino. Note-se mais uma vez, porém, que esse "pombalismo» se não mostra cego, parecendo conciliar-se ao invés com uma decidida vontade de «aggiornamento" do despotismo iluminado. Relembro o regalismo mitigado que inspira o Prólogo do ms. 198, revelador ainda de que existia no Autor o desejo duma autoridade régia que soubesse pactuar com o direito dos Povos; que esse desejo de renovação não ia até à defesa do regime parlamentar, mostra-no-lo todavia o corpo do poema, ao troçar do regime iinglês.

Culto das luzes da razão, crítica áspera da soberba e imoralidade fidalgas, sátira mordaz da ignorância e relaxamento clericais, desejo de incremento científico, técnico e comercial, apostolado filantropo (recordem-se as acusações feitas à inumanidade da escravatura negra e índia e às bárbaras práticas utilizadas por Ingleses e Espanhóis na dominação colonial), espírito de tolerância (lembre-se a referência depreciativa a Pina Manique e uma ou outra nota satírica sobre o "zelo" inquisitorial), desejo de justiça social e de maior abertura ao direito dos Povos no regime monárquico, não se radicam porém. no autor implícito de $O$ Reino da Estupidez - e mais explicitamente no-lo mostra a versão $B$ - num "filosofismo» ateu ou simplesmente deísta, mas numa religiosidade católica exigente, que busca os seus padrões na simplicidade e austeridade evangélicas; daí a modacidade da sátira, no ms. 198, aos desmandos morais propiciados pela «ilustração» francesa, as referências negativamente jocosas a Voltaire, aos aespíritos fortes» e ao generalizado apreço inglês pelos "manes de Locke", a troça da multiplicação das seitas protestantes $\mathbf{O}$ autor implícito da versão $B$ do poema parece enquadrar-se, assim, na ilustre geração de intelectuais católicos progressistas que, nas décadas finais de Setecentos e primeiras de Oitocentos, se mostraram desejosos de uma renovação, profunda mas não revolucionária, do absolutismo português e da sociedade beata, desequilibrada $e$ inculta que o sustentava. Representam-na figuras como António Ribeiro dos Santos, D. Fr. Alexandre da Sagrada Familia, Fr. José do Coração de Jesus, cujo austero Catolicismo, 
admirador do Cristianismo primitivo, se alia ao arejamento intelectual, ao desejo de separação de Igreja e Estado e ao anelo de alguma mutação social e política, sem quebra, todavia, do regime vigente.

Se deste desenho do perfil do autor implícito de $O$ Reino da Estupidez, a partir da versão $B$ do poema, quisermos passar à tentativa da sua identificação com uma dada personalidade histórica, algumas perplexidades se levantam. Como ficou já dito, o poema anda comummente atribuído ao brasileiro Francisco de Melo Franco, que teria, ou na sua confecção ou apenas na sua divulgação clandestina, beneficiado do auxílio de José Bonifácio de Andrade e Silva. É essa a autoria registada no Dicionário Bibliográfico de Inocêncio Francisco da Silva, essa também a que apontam J. M. da Silva Pereira, Teófilo Braga, Alberto Pimentel e, mais recentemente, quantos se têm referido a este assunto $\left({ }^{88}\right)$. Todas estas atribuições são, porém, tardias em relação ao aparecimento de $O$ Reino da Estupidez, que circulou anónimo ou sob o pseudónimo de Fabrício Cláudio Lucrécío, ostentado por algumas cópias manuscritas $\left({ }^{87}\right)$, sem que ninguém tivesse então sido capaz de identificar com certeza o seu autor. N'O Zello, um poema manuscrito em sete cantos guardado na Biblioteca da Academia das Ciências de Lisboa (ms. n. ${ }^{\circ}$ 655) e enderaçado com acrimónia pelo Autor escondido no pseudónimo Patrício Prudente Calado - «aos adoradores da Estupidez", diz-se que o aparecimento do Reino (...) tinha alvoroçado Coimbra, originando, com aplauso ou com repulsa, múltiplos alvitres sobre quem o escrevera. Lê-se aí, numa sequência da acção que nos mostra Mercúrio descendo à Cidade, disfarçado de estudante, para averiguar quem

${ }^{(\infty)}$ Cf. J. M. da Silva Pereira, Os varōes illustres do Brasil durante os tempos coloniaes (3..$^{2}$ ed., Rio de Janeiro - Paris, 1868, vol. II, pp. 183-195); T. Braga, Historia da Universidade de Coimbra (vol. III, Lisboa, 1898, pp. 677-697) e Filinto Elysio e os dissidentes da Arcádia (Porto, 1901, pp. 448-479); Alberto Pimentel, Poemas herói-cómicos portugueses (Porto - Rio de Janeiro, 1922, pp. 149-151); António Cândido, Formação da Literatura Brasileira (1.0 vol., 2.a ed., S. Paulo, 1964, pp. 163-166); José Paulo Paes e Massaud Moisés, Pequeno Dicionário de Literatura Brasileira (S. Paulo, 1968, p. 104).

${ }^{87}$ ) O pseudónimo surge, por exemplo, no cód. $\mathrm{CXXX/2-10} \mathrm{da}$ Biblioteca Pública de Évora (T. Braga afirma erradamente, em Filinto Elisyo..., p. 471, que um dos ms. do Reino da Estupidez guardados nesta biblioteca indica Melo Franco como autor do poema. Também se engana Luís de Albuquerque ao afirmar, a p. 70 da introdução da sua edição do poema, que o ms. 370 da B. Pública de Braga, efectivamente anónimo, está atribuído a Fabrício Cláudio Lucrécio). 
fosse o autor que tanto zangara Minerva pelas acusações dirigidas à sua Universidade dilecta:

«Da risonha Cidade o Deus alado

As mal calçadas ruas passeando,

Em lépida batina enrodilhado,

Por toda a parte os olhos vai lançando

Té que ouviu numa casa vozeria,

E para ela correndo os passos guia.

Era a lógea do Alves: lá se achava

Uma corja de mestres de guedelha, Que batendo nas mesas recitava

Acerca do Poema (...)

O Silva sustentava que a obra fora

Engendrada em cabeça de mais peso.

o Santos diz que ouvira a uma Senhora,

Oh caspite, que o traz em ferros preso,

Que sabia quem era, e não passava

Daqueles a que a malta fofa honrava.

O magro Bruxo, erguendo a voz cansada,

O desmente, dizendo que o fizera

Um sujeito assistente na Calçada.

O Martins, praguejando, afirma que era

o Caldinhas, que em doce paz descansa

Nas regiōes da astuta e sábia França.

Outro disse dali que tinha sido

O pequeno Malhão, outro que o velho,

Outro disse que fora produzido

Por homens de saber e de conselho,

Que nas letras há munto ( $\mathrm{sic}$ ) floresciam,

Opinião que os mais todos seguiam» $\left({ }^{88}\right)$.

${ }^{(8)}$ Ms. vermelho n. 655 da Bibl. da Ac. das Ciências, c. 4., pp. 14-14. ${ }^{\text {a }}$ Assinale-se que, pelo fragmento transcrito, se conclui que entre os nomes alvitrados como de autores possíveis do Reino da Estupidez estiveram os de Sousa Caldas, que em 1785 se encontrava efectivamente em França, e dos dois irmãos Malhão (António e Francisco), que ficaram célebres na boémia estudantil da época (António Malhão inspirou a Anacleto da Silva Morais um poema herói-cómico, $A$ Malhoada, de que fala Alberto Pimentel a pp. 101-111 de Poemas Herói-cómicos portugueses, Porto - Rio de Janeiro, 1922). Se o Santos referido é António Ribeiro dos Santos, o autor de $O$ Zello não o inculca como autor do Reino da Estupidez. 
Nenhum nome chega a ser definitivamente acusado. Na intriga montada por $O$ Zello, o réu vem a ser uma personagem mitológica: a musa Egina, filha do rei Esopo da Beócia, amada por Júpiter e condenada, por vingança de Juno que ela denegrira, a sofrer no exílio infindáveis ardores passionais. 0 seu pendor para a sátira, exacerbado pela dura pena imposta, tinha-a levado a inspirar ataques a instituições e homens respeitáveis; fora ela também que viera a Coimbra, sabendo "que a jente / Por cousa tem ali de grande monta / Uma língua arrogante e maldizente» - e, a troco de dinheiro para vinho, levara certo Fataça, um pobre louco, a aceitar escrever as calúnias de $O$ Reino da Estupidez, que ela ditava. Egina está arrependida... e Apolo manda queimar o poema e quantos papéis tinham surgido a aplaudi-lo, sempre inspirados pela Musa.

Tive ocasião de percorrer alguns desses "papéis» elogiosos, bem como outros acusadores - estes em maior número - aparecidos logo após o Reino (...), sem que em qualquer deles, encontrasse sequer sugeridos os nomes de Francisco de Melo Franco ou José Bonifácio de Andrade e Silva como seus presumíveis autores ${ }^{\left({ }^{80}\right)}$. A ser verdade o que diz Teófilo Braga $\left({ }^{80}\right)$, caberia a José Agostinho de Macedo, numa versão de 1813 de Os Burros, a primeira atribuição do Reino (...) a Melo Franco, associando-lhe, aliás, não José Bonifácio, mas um outro estudante, Francisco José de Almeida. Aí se leria:

\section{«Tu, que ao prosa Diniz ditaste o Hissope E a Estupidez ditaste a Almeida e Franco".}

- versos que todavia se não acham na edição de 1868 de $O s$ Burros, que consultei e que se dá por mais completa e autêntica do que a anterior (de 1827, segundo creio). Diz Teófilo que Agostinho de Macedo devia ter colhido em Coimbra aquela tradição, que juntava na autoria dum poema tão anti-clerical e acusador do obscurantismo os nomes de dois pobres estudantes vítimas da Inquisição ${ }^{\left({ }^{81}\right)}$. Ambos participaram efec-

$\left({ }^{80}\right)$ Muitos desses textos acusadores ou elogiosos se guardam, por exemplo, no ms. 1325 da BGUC, no ms. 370 da B. P. de Braga ou no ms. 571 da B. P. do Porto.

$\left({ }^{\infty}\right)$ Filinto Elysio e os dissidentes da Arcádia, Porto, 1901, pp. 470-471; Hist. da Universidade de Coimbra, vol. III, p. 696.

(") Vários textos suscitados pelo aparecimento do Reino da Estupidez parecem inculcar, pelo menos, uma autoria dupla. Na Ode a Fileno (B.G.U.C., ms. 1327, f. 18) diz-se, por ex., com ironia, que a Estupidez «é mãe / Dos dois estupidantes, dois rapazes». No Dialogo de 
tivamente, com mais catorze pessoas (entre as quais seis outros estudantes), no auto-de-fé que teve lugar em Coimbra a 26 de Agosto de 1781. Francisco de Melo Franco, «estudante médico" (então com 24 anos, pois nascera nas Minas do $\mathrm{Pa}$ racatú, perto de Pernambuco, em 1757), recebeu como pena a ida "para Rilhafoles a arbítrio», constando das acusações que lhe eram movidas o seguinte: «Herege, naturalista, dogmatista, deísta, negava o matrimónio da Igreja, afirmando que bastava o simples consenso das pessoas, o que aconselhava a sua concubina, e que pela união das vontades estavam legitimamente casados». Francisco José de Almeida, natural de Lisboa, e "estudante matemático» $\left({ }^{82}\right)$, foi por sua vez condenado a ficar "recluso a arbítrio»; dele se diz: «Herege, naturalista, deísta, e seguia os erros dos mais e outros muitos. Era tão licencioso que até andava carretando as meretrizes para os mais, fazendo sarralho ( $\mathrm{sic}$ ) a sua própria casa, afirmando não ser pecado». Idênticos erros são, aliás, imputados aos restantes seis estudantes, todos enviados, como Melo Franco, para a casa correccional de Rilhafoles, em Lisboa $\left({ }^{93}\right)$.

Segundo os dados colhidos no Arquivo da Universidade de Coimbra, fora em Outubro de 1776 que Francisco de Melo Franco fizera a sua primeira inscrição na Universidade, como aluno do primeiro ano "filosófico», tendo apresentado certidão

dois Bedeis da Universidade contra o poema da Estupidez (B.G.U.C., ms. 1325 , cf. $139 \mathrm{v}^{\circ}{ }^{\circ}$ afirma-se que «Os autores daquela infame empresa / / Nem respeitam das Musas o decoro, / Nem conhecem as leis da natureza».

${ }^{\left.{ }^{22}\right)}$ Segundo dados colhidos no Arquivo da Universidade, Francisco José de Almeida realizou a sua inscrição no $10^{\circ}$ ano matemático em 1775, no $2 .^{\circ}$, em 1776 e no $3 .^{\circ}$ em 1778; em 1777, matriculara-se no $1 .^{\circ}$ ano médico; não constam do Arquivo quaisquer outros dados relativos a outras inscrições nas Faculdades de Medicina ou de Matemática, o que parece significar que não concluiu os seus estudos, cortados pela perseguição inquisitorial. Também do final do ano lectivo de 78-79 data a interrupção temporária dos estudos de Melo Franco, como adiante se dirá. Francisco José de Almeida veio a publicar, em 1794, um Tratado de Educação Física de Meninos; outra obra, com o mesmo título e na mesma data, saiu da pena de Melo Franco, o que pode ter contribuído para a aliança dos nomes dos dois estudantes, coetaneamente vítimas da Inquisição.

(क) Estes dados constam dum documento conservado na livraria do Visconde da Trindade, pertencente à Biblioteca Geral da Univ. de Coimbra. Trata-se da Lista dos penitenciados pelo St. ${ }^{\circ}$ Officio q. sahiraõ no Acto público da Fé, q. se fez em Coimbra na Salla do mesmo Tribunal em 26 de Agosto de 1781. Da colecção de documentos relativos à Inquisição existentes naquela livraria foi publicado um Inventário, organizado por Maria Isabel Ribeiro de Faria e Maria da Graça Pericão de Faria, no vol. XXXIII do Boletim da Biblioteca da Universidade de Coimbra, 1977, pp. 235-441. 
de exame de gramática latina; no ano lectivo seguinte, isto é, 1777-78, realizara a sua primeira matrícula no primeiro ano médico (tendo apresentado certidões de exame do $10^{\circ} \mathrm{e} 2 .^{\circ}$ anos matemáticos e do $1 .^{\circ}, 2^{\circ}$ e $3 .^{\circ}$ anos "filosóficos»), de que só prestara provas, todavia, em Julho de 1779, por ter deixado de as fazer «no tempo competente» $\left({ }^{94}\right)$. Terão começado por então os seus problemas com a Inquisição de Coimbra. Na verdade, só volta a inscrever-se na Faculdade de Medicina (2. ano) em Outubro de 1782 , em circunstâncias que não parecem muito normais, dado que o Secretário da Universidade, Gaspar Honorato da Mota e Silva - cujo mau conhecimento da língua latina é jocosamente recordado no Reino da Estupidez-, só lança o assento do acto, por despacho do Vice-Reitor, D. Carlos Maria de Figueiredo Pimentel (o lente de Teologia tão satirizado no poema), a 12 de Julho de 1783, afirmando que o estudante se "apresentara" por ordem do mesmo Vice-Reitor. Houve assim, na carreira académica de Melo Franco, um hiato de três anos (79-80, 80-81, 81-82), ligado sem dúvida a circunstâncias relacionadas com o auto-de-fé de Agosto de 1781 em que participou. Provavelmente terá ele estado preso nos cárceres inquisitoriais de Coimbra até essa data, a partir da qual terá permanecido por um ano na casa de Rilhafoles, em Lisboa. Em Outubro de 1782, realizou, como ficou dito, a sua matrícula no $2 .^{\circ}$ ano médico, completando depois o curso, sem incidentes, no ano lectivo de 1785-86. Entretanto, por Dezembro de 1784 ou inícios de 1785, circulava anonimamente o Reino da Estupidez, causando em Coimbra a celeuma já evocada.

Não pude infelizmente até à data encontrar o processo inquisitorial de Melo Franco, todavia assinalado no Inventário dos Processos da Inquisição de Coimbra (1541-1820) que publicou em 1972 Luiz de Bivar Guerra, segundo documentos

(24) Cf. Livro n. 1 de Actos de Medicina, f. 137. Segundo os estatutos pombalinos (Livro III, $1 .^{a}$ parte, título I, caps. II e III) os estudantes não podiam ingressar na Fac. de Medicina sem possuirem conhecimentos prévios de Latim, «Filosofia» e Matemática; a matrícula no $3 .^{\circ}$ ano médico estava também condicionada pelo domínio do Grego (aconselhava-se ainda vivamente o estudo do Francês e do Inglês). Esses conhecimentos podiam ser obtidos na Universidade, segundo os cursos nela normalmente professados, ou granjeados pelo esforço pessoal do aluno; neste caso, devia ele provar a sua competência nas matérias «preparatórias» através de exames feitos perante o Reitor, apresentando depois, no acto de matrícula em Medicina, as certidões desses exames. $t$ o caso de Francisco de Melo Franco que, como se conclui, trabalhou com afinco no seu $10^{\circ}$ ano «propedêutico». 
pertencentes ao Arquivo do Tribunal de Contas $\left({ }^{85}\right)$. Aí se colheriam com certeza elementos importantes para conhecer melhor o perfil ideológico do estudante brasileiro. $\mathrm{Na}$ ausência deles, os escassos dados biográficos que aqui ficam reunidos podem, pelo menos, corrigir asserções frequentemente feitas a propósito da juventude de Melo Franco: nem ele passou quatro anos recluso em Rilhafoles, nem, muito menos, deveu ao Reino da Estupidez os seus desencontros com a Inquisição $\left({ }^{90}\right)$.

Concluída a formatura em Medicina, Melo Franco conquistou em Lisboa, na prática da sua profissão, uma certa notoriedade, vindo a tornar-se sócio da Academia das Ciências. Só em 1817 abandonou a nossa capital para regressar ao Brasil como médico particular da Arquiduquesa de Austria, esposa do futuro D. Pedro I (IV de Portugal). J. M. Pereira da Silva diz, não sei se com fundamento, que durante as invasões francesas Melo Franco não assumira, por receio, qualquer posição pública, quer nacionalista, quer pró-napoleónica; mas que, uma vez no Rio, aderiu claramente aos ideais vintistas, o que lhe teria acarretado graves desavenças com a Corte, em parte responsáveis, juntamente com a inadaptação ao clima e azares financeiros que lhe dissiparam os bens, da morte sobrevinda em 1823. Publicara entretanto algumas obras ligadas com a sua formação médica: salientemos um tratado de puericultura, um tratado de higiene, um estudo sobre as "febres» e a sua relação com o clima $\left.{ }^{\left({ }^{87}\right.}\right)$. Inocêncio atribui-lhe ainda ${ }^{\left({ }^{88}\right)}$ a Medicina Teologica, ou Supplica humilde, feita a todos os Senhores Confessores, e Directores, sobre o modo de proceder com seus Penitentes na emenda dos pecados, principalmente da Lascivia, Colera e Bebedice ${ }^{\left({ }^{9}\right)}$ - uma curiosa obra anónima que, surgida em 1794 com licença da Real Mesa da Comissão (para a qual tinham passado, em 1787, as atribuições

${ }^{\left({ }^{95}\right)}$ Inventário (...), Paris, Centro Cultural Português da Fundação Calouste Gulbenkian, 1972, t. II, p. 429. O processo de Melo Franco é aí o n. ${ }^{\circ} 34$ do maço 662. No Arquivo Nacional da Torre do Tombo, onde hoje se encontram os processos, não encontrei o de Melo Franco (como de nenhum dos penitenciados de 1781) entre os da Inquisição de Coimbra.

${ }^{(\infty)}$ Cf. o que afirma Pereira da Silva, op. cit., vol. II, p. 184.

(") Consulte-se o Dicionário Bibliográfico Português, de Inocêncio Francisco da Silva, vols. III (pp. 10-11), VI (pp. 175-179) e IX (p. 344). Ver ainda Luís de Albuquerque, op. cit., pp. 131-132. Afirma Inocêncio (vol. III, p. 11) que se diz ter Melo Franco deixado várias poesias manuscritas, entre as quais Noutes sem somno, que Pereira da Silva, op. cit., II, p. 194) afirma terem sido concebidas no cárcere e revelarem a tortura do sofrimento. Tê-las-á conhecido?

(承) Dic. Bibliog., vol. VI, pp. 175-179.

() Existe um exemplar da obra na B.G.U.C. (7-28-6-9). 
da Mesa Censória), foi mandada recolher por ser julgada heterodoxa, originando a extinção do organismo que a aprovara. Narra Inocêncio que só por acaso viera a saber, já depois de impresso na vol. III do Dicionário Bibliográfico o artigo sobre Melo Franco, que fora ele o autor da polémica obra. Devera a informação ao padre oratoriano Joaquim Manso, bibliotecário de D. João VI, que no Rio de Janeiro ouvira a confissão da autoria ao próprio Melo Franco: o médico tinha-lhe na ocasião mostrado mesmo um exemplar da obra corrigido e aumentado, pois pensava numa reimpressão que a morte prematura lhe não permitiu levar a cabo.

Todas estas obras nos identificam Melo Franco como um desempoeirado espírito voltado para o experimentalismo, tolerante, filantropo e detractor da religiosidade obtusa e fanática. A Medicina Teológica, por exemplo, terá parecido herética por inculcar que não era com remédios exclusivamente espirituais e ameaças de fogo eterno que poderiam curar-se certos "pecados", radicados em descontrolos físicos cujo domínio mais careceria de cuidados médicos; por isso o confessor deveria aliar à sabedoria teológica algum conhecimento da fisiologia do corpo humano e das virtudes dos fármacos...

Este arejamento intelectual condiz sem dúvida com o teor da sátira desenvolvida no Reino da Estupidez; não basta, todavia, para assegurar que caiba a Melo Franco a autoria do poema, tanto mais que podem contrariar tal hipótese algumas circunstâncias que julgo ponderáveis. Vimos já que, na altura em que o Reino da Estupidez circulou, nenhuma suspeição parece ter sido lancada sobre o nome do estudante brasileiro, então finalista de Medicina, duramente marcado pelo estigma duma perseguição inquisitorial. A ser verdade o que diz Pereira da Silva sobre a prudência de Melo Franco, dado o seu passado, durante as invasões francesas, mal se imagina que, recém-saído de Rilhafoles e prestes a concluir o seu curso, se arriscasse a compor e a fazer largamente circular, ainda que sob cauteloso anonimato, uma obra de tão escaldante mensagem como o Reino da Estupidez, onde se satirizava com particular relevo D. Carlos Maria de Figueiredo Pimentel, lente de Teologia - o Vice-Reitor que lhe permitira a readmissão na Universidade. Acrescente-se que, se Melo Franco veio a perfilhar, em 1820, ideias liberais avançadas, elas não se coadunam com o perfil ideológico do autor implícito do Reino da Estupidez na sua versão $B$ (mais de duas décadas, é certo, tinham passado), também inidentificável com um estudante que, por motivos que ignoro, deu de qualquer modo ensejo à Inquisição para o acusar de *herege», «naturalista», «deísta», etc. 
Outros argumentos contribuem ainda para a perplexidade que me causa a atribuição do poema herói-cómico a Melo Franco. 0 teor da sátira, focando com tanta demora, tanta minúcia e tanta crueza a crise universitária, conduz à suposição de que terá sido preferentemente seu autor alguém que conhecesse "por dentro" a Alma Mater num amplo percurso cronológico, dadas as muitas referências feitas ao período pré-pombalino - quesitos que um estudante, embora finalista, preencheria dificilmente. Notória é também a informação que esse "alguém» mostra ter de problemas ligados às matérias jurídicas: basta lembrarmos o relevo que no Prólogo se concede à complexa questão das relações entre o Estado e a Igreja ou entre o poder monárquico e o direito dos povos. Seriam todos estes conhecimentos e a vasta informação que em tantos domínios o poema revela - da política europeia aos meandros da vida da capital - compatíveis com a experiência e o saber dum aluno de medicina? E que dizer das preocupações linguísticas e dos conhecimentos literários desse estudante que, uma vez médico distinto, só produziu obras ligadas com a sua esfera profissional, ainda que em relação estreita com problemas do foro moral e pedagógico? A ser ele o autor do poema, também para estranhar pareceria que não tivesse deixado no poema, em referências de carácter histórico e sócio-económico, ou até só em imagens poéticas, quaisquer vislumbres de motivos brasileiros que, se constituiriam novidade em texto escrito no registo «sério», muito travado pelo decoro clássico, teriam acesso franco num texto satírico escrito no registo «vulgar».

$O$ conhecimento da versão $B$ do Reino da Estupidez veio, pois, alimentar as dúvidas que me suscitava a atribuição do poema a Melo Franco. Mais improvável se me tornou também a contribuição, geralmente aludida, que lhe teria dado José Bonifácio de Andrade e Silva, já afirmada por Inocêncio a partir de elementos que ignoro. Tê-la-á fundamentado a circunstância de ser José Bonifácio autor de uma Epistola escrita de Coimbra no começo da primavera de 1785 - ano em que cursava na Lusa Atenas o $20^{\circ}$ ano jurídico e o 2: ano "filosófico» - e publicada em 1825 nas Poesias de Américo Elísio saídas em Bordéus? ( $\left.{ }^{100}\right)$ Essa composição constitui um convite dirigido a Armindo, «em quem liberal a natureza / Uniu uma alma grande a um peito humano", incitando-o a vir re-

(100) Cf. Poesias de Américo Elísio, vol. I da col. «Obras de José Bonifácio de Andrade e Silva», Rio de Janeiro, Imprensa Nacional, 1946, pp. 31-34. 
pousar por algum tempo no campo ao calor da amizade. Alguns leitores do poema terão identificado Armindo com Melo Franco (considerado como o autor do Reino da Estupidez) $\left({ }^{101}\right)$, dadas as alusões de Américo Elísio ao pendor satírico do amigo servindo-se de imagens alusivas ao império da Estupidez no mundo:

«Voltando para casa sossegados

Com teu modo socrático, mordendo

Irás no velho mundo, que empeiora.

Graciosas pinturas delicadas

De puros Zeros, que per si não vivem,

Do político Mévio barrigudo,

Dignas do grande Pope irás fazendo.

Desmiolada cabeça, em cujo oco

Podem melhor girar trezentos mundos

Do que no espaço do divino Newton!

Quantos pequenos embriões das letras

No vasto alcáçar da benigna deusa

Alojados verás à perna solta!

Apática manada que vegeta,

Enquanto poucos vivem. - Grande deusa!

Coeterna do caos! mãe dos asnos!

Estupidez afável que derramas

No calejado peito de teus filhos

Insípida alegria. - Ou abrindo a fonte

Fazes correr em bica mil palavras

Escoltadas de simbolos, de enigmas;

A cuja vista tímida a verdade,

Coitadinha verdade! espavorida

Desampara a cadeira de Minerva;

Reina no mundo, pois, nasceste deusa;

$\mathrm{E}$ ao redor do teu trono bocejando

Teus gordos filhos vejas descansados

Mil sonolentos vivas entoarem!

Eu não desejo, nem deseja Armindo,

No altar da razão queimar-te incenso».

Note-se, porém, que esse Armindo é dado por residente na "Corte», onde gasta "anos inteiros» com "rostos mil fingidos» e fátuos amores - o que não condiz com as ocupações de Melo Franco em 1785; e que as referências ao império da

(101) Assim faz António Cândido em Formação da Literatura Brasileira, 2. ${ }^{\mathrm{a}}$ ed., S. Paulo, Liv. Martins Ed., 1964, p. 165. 
Estupidez, precedidas pela citação do nome de Pope, o grande responsável da alegoria que a deificara, se fazem no âmbito genérico duma crítica ao "velho mundo" onde tal deusa pontifica, obrigando a Verdade a desamparar, "espavorida", a «cadeira de Minerva». Imagens que dão a Estupidez como deusa "coeterna do caos» remetem directamente para The Dunciad de Pope, que gozou de grande favor nos nossos meios intelectuais de então - não para o Reino da Estupidez que circulou em Coimbra, por 1785. Acrescente-se que o clima ideológico que na composição se respira não é o da versão $B$ do Reino da Estupidez. Basta lembrarmos que o final da Epistola insiste no convite dirigido a Armindo para buscar o "porto» dum remanso rústico, lembrado-lhe, em atitude admirativa, que Voltaire, o "vate dos filósofos", viveu contente retirando-se "na aprazível Ferney» e que "o pensador Rousseau sublime» terminou os seus dias «herborizando". As orientações políticas que José Bonifácio veio a perfilhar, coadunáveis com estas premissas, não se harmonizam também com o clima ideológico da versão $B$ do Reino da Estupi$\operatorname{dez}\left({ }^{102}\right)$.

Se o conhecimento do ms. 198 do espólio de Garrett pôde, pois, levar-me a duvidar da autoria tradicionalmente apontada para o poema herói-cómico, fez-me considerar, ao invés, com renovado interesse, as suspeições que, na altura da sua circulação, se avolumaram sobre António Ribeiro dos Santos, então lente substituto na Faculdade de Cânones. Como é sabido, o conhecido jurista-poeta veio mesmo, em 7 de Março de 1785, a ser irradiado da Universidade por decisão régia inspirada pelo Principal Mendonça, que o considerou autor da obra na sequência da pouca simpatia que já lhe consagrava, dado o pombalismo que lhe atribuía e certas divergências de carácter pedagógico surgidas desde $1783 \mathrm{em}$ congregações da Faculdade $\left.{ }^{103}\right)$. Não foi, aliás, por muito tempo que António Ribeiro dos Santos esteve (no Porto, donde era natural) afastado da docência, pois já no ano lectivo de 1786-87 se achava de novo ao serviço da sua Faculdade, sob o reitorado de D. Francisco Rafael de Castro, que viera substituir, logo em 1786, o Principal Mendonça.

( $\left.{ }^{102}\right)$ Reeditadas em 1861, por Laemmert, as Poesias de Américo Elígio saíram acompanhadas por um Esboço Biográfico do Autor (reproduzido na edição de 1946 há pouco citada), onde, aliás, nenhuma referência é feita à participação de José Bonifácio de Andrade e Silva, falecido desde 1838, na confeç̧ão do Reino da Estupidez.

( $\left.{ }^{100}\right)$ Vid. José Esteves Pereira, António Ribeiro dos Santos. O pensamento filosófico-político, Coimbra, 1980, pp. 19-31. 
Na correspondência que, do seu «exílio», manteve com amigos, António Ribeiro dos Santos refere-se às suspeitas do Reitor, declarando-se inocente da "culpa» da autoria do Reino da Estupidez. Não era próprio do seu feitio denegrir a Instituição a que pertencia - afirmava o canonista; e, advogando a sua causa, procurava destruir um argumento frequentemente invocado pelos que o incriminavam - a sátira feita no poema a membros dos Colégios de S. Pedro e de S. Paulo, contraposta à notória ausência de críticas a membros do Colégio dos Militares a que pertencia ele próprio, Ribeiro dos Santos; ora - dizia o canonista - se lhe coubesse a autoria do poema, teria ele cometido essa imprudência, que tão facilmente poderia denunciá-lo? ( $\left.{ }^{104}\right)$

Estas afirmações de Ribeiro dos Santos, que veio a tornar-se até à morte, ocorrida em 1818, uma veneranda personalidade da cultura portuguesa ligada aos elevados meios lisboetas, têm tido a força bastante para ilibá-lo da autoria do Reino da Estupidez: assim procedeu Teófilo Braga, assim procede José Esteves Pereira na recente dissertação de Doutoramento que consagrou ao pensamento do jurista. $\mathbf{O}$ conhecimento da versão $B$ do poema pode todavia alterar, pelo menos, a serenidade dessa convicção, tão bem quadra com Ribeiro dos Santos o perfil do autor implícito deduzível do texto.

Com ele condizem a cultura que informa a sátira, a competência jurídica que ela revela e o conhecimento mostrado da vida universitária pré- e pós-pombalina (recordemos que a carreira estudantil de Ribeiro dos Santos, nascido em 1745, se iniciou em 1764, data da sua primeira matrícula em Cânones, e que em 1771, obtido o grau de Doutor, iniciou as suas

(104) Cf. L. F. Carvalho Dias, «Algumas cartas do Doutor António Ribeiro dos Santos», in Revista Portuguesa de História, t. XIV, 1974, p. 459; cf. ainda o texto aduzido por Esteves Pereira, na n. 2 da p. 30 da sua dissertação de Doutoramento consagrada a Ribeiro dos Santos. Os grandes colégios universitários de Coimbra nutriam entre si rivalidades, que A. R. dos Santos considerava estarem também ligadas às perseguiçóes de que foi alvo. O Colégio dos Militares, de cuja livraria se conserva um inventário na B.G.U.C., era considerado um centro de ideologia heterodoxa (cf. Esteves Pereira, op. cit., p. 28, n. 2). Nele habitaram Ribeiro dos Santos, Raimundo Nogueira, Pascoal de José de Melo Freire. Como pudemos ver, a versão $B$ do Reino da Estupidez, não isentava de críticas o Colégio dos Militares; e troçava abertamente da Ordem Militar de Santiago, à qual pertencia precisamente António Ribeiro dos Santos. O canonista, recém-doutorado, recebera em 1772 uma das becas existentes no referido Colégio, tendo tomado para o efeito o hábito da Ordem respectiva a 21 de Set. de 1772 (Esteves Pereira, op. cit., p. 9). 
actividades docentes, tornando-se Opositor às cadeiras da. quela Faculdade).

$\mathrm{Da}$ versão $B$ do Reino da Estupidez ressalta, como ficou dito, a adopção pelo seu autor dum regalismo mitigado unido ao desejo duma certa correç̧ão da prática absolutista posiçōes que, por 1784-85, altura da circulação do poema, eram precisamente as de Ribeiro dos Santos. Se, na obra que publicara em 1770 (para se apresentar, já obtida a formatura, às provas de suficiência e repetição que precediam o Doutoramento) - De Sacerdotio et Imperio selectae Dissertationes -, António Ribeiro dos Santos se revelara, como diz Esteves Pereira, "claramente regalista e febronista ( $\left.{ }^{108}\right)$, evoluíra de facto para posições mais conciliadoras no tocante às relações entre a Igreja e o Estado e entre o poder régio e os direitos dos povos. Prova-o inequivocamente a censura que dirigiu ao projecto do Novo Código de Direito Público português concebido pelo seu colega universitário Pascoal José de Melo Freire, lente da cadeira de Direito Pátrio, em trabalhos desenvolvidos particularmente entre 1783 - ano em que deixou a docência para se instalar em Lisboa - e $1789\left({ }^{108}\right)$. Pelo teor dos argumentos desenvolvidos nessa polémica - particularmente a defesa da revitalização de instituições que haviam caído em desuso, como as cortes, e que podiam tornar-se correctivos do absolutismo -, António Ribeiro dos Santos pôde mesmo ser indevidamente acusado de «monarcómaco» e, também indevidamente, considerado representante dum pré-liberalismo ( $\left.{ }^{107}\right)$.

Com o perfil ideológico do canonista, integrado no progressismo católico do final de Setecentos, se harmonizam perfeitamente também a sátira violenta dirigida ao Clero (sobretudo ao regular), relaxado e ignorante, associada ao louvor da «santidade» da religião primitiva e à desautorização do «filosofismo» materialista ou deísta. Recorde-se a obra

(106) Op. cit., p. 27.

( $\left.{ }^{500}\right)$ projecto veio a ser publicado postumamente em 1844, ano em que também foram editadas as Notas ao plano do Novo Codigo de Direito Publico de Portugal (...) feitas e appresentadas na Junta de Censura e Revisão pelo D.or António Ribeiro em 1789. Os trabalhos destinados ao projecto tinham sido estabelecidos por decreto de 31 de Março de 1778. Em 25 de Julho de 1788 Ribeiro dos Santos tomara posse como deputado da Junta de Censura e Revisão do Novo Código. A dissertação de Doutoramento de José Esteves Pereira, tantas vezes já citada, é especialmente consagrada ao estudo da polémica que se verificou entre Melo Freire e Ribeiro dos Santos.

(10r) Cf. Esteves Pereira, op. cit., passim; e ainda: J. S. da Silva Dias, Pombalismo e teoria política, Centro de História da Cultura da Universidade Nova de Lisboa, 1982, pp. 37-38 particularmente. 
publicada anonimamente por Ribeiro dos Santos em 1787 $A$ verdade da Religião cristã - , cuja apologética, mostrando os benefícios que podem resultar da articulação da necessidade da Religião com a prática do poder, comporta uma cerrada refutação de argumentos expendidos pelos "filósofos», particularmente Voltaire e Rousseau, e uma corajosa análise de problemas como o celibato e a desmoralização na vida conventual ${ }^{108}$ ). Acrescente-se que António Ribeiro dos Santos, sem contestar embora a organização tradicional da sociedade, não possuía da nobreza, como o autor do Reino da Estupidez, uma opinião lisonjeira. Numa carta, escrevia o canonista, por exemplo, que aum fidalgo conta os seus mestres no número dos seus criados» $\left({ }^{109}\right)$. Do pouco apreço em que tinha o ambiente das Faculdades jurídicas coimbrãs, fale este fragmento duma epístola a Almeno (escrita em Lisboa, em 20 de Agosto de 1786) que ficou inédito:

«Daqui te mando por penhor de amigo, Nunca esquecido do que a ti te devo, Uns poucos rudos versos, que o não pude

Fazer lá do Mondego: amarrotado

De mil tombos e chuvas e tormentas Apenas lá cheguei, eis envolvido Me vejo logo num tropel de estudos, A que chamam Direito: rebentavam Daqui dali os bandos espantosos

De mil Doutores de capelo e borla, Que quais medonhos Turcos de Bizâncio De retorcidos, bárbaros bigodes, C'o só seu nome e fama o donzel Coro Das melindrosas musas afugentam» $\left({ }^{110}\right)$.

E ainda, aliás, numa ode a Almeno que traça, no início do reitorado do Principal Castro, que tanto procurou auxiliar, este quadro do lamentável estado de decadência a que a Universidade, em geral, tinha chegado:

«O santo templo da imortal memória

Que o grão Diniz às Musas levantara

Inda por terra jaz: magoa, Almeno, Ver o fatal destroço.

\footnotetext{
(108) Cf. Esteves Pereira, op. cit., pp. 252-289.

(109) Cf. L. F. Carvalho Dias, op. cit., pp. 427 e 494 (nota à carta 7.a). Cf. também Esteves Pereira, op. cit, pp. 340-343.

${ }^{(110)}$ A epístola encontra-se no espólio de Garrett (ms: 202-G), entre papéis que pertenceram a seu Tio. Foi publicada em versão mais reduzida, sem estas referências satíricas aos Doutores de Coimbra, nas Poesias de Elpino Duriense, I, 1812, pp. 95-98.
} 
Não ficou pedra sobre pedra; bando

De bárbaros selvagens sem piedade

Deram feros sobre ele, e o derrubaram

Dos altos fundamentos.

Eis lida Castro pelo erguer, e destro

C'o sabedor compasso de Urania

Desenha ũa obra que assoberbe os astros, Mais alta que a primeira.

Porém que montam splêndidos projectos?

Falece gente a trabalhar na empresa;

E os poucos d'arte e esforço sós não podem

Alçar a imensa mole» (111).

Não é ilógico pensar que a "mágoa» de Ribeiro dos Santos ao contemplar tanto "destroço" possa ter-se expandido na sátira mordaz do Reino da Estupidez, tanto mais que da pena do canonista não está ausente o tom pitoresco dum humor bem-disposto ou acre $\left({ }^{112}\right)$. Para ele, como para o autor do poema herói-cómico, apenas havia para elogiar, em Coimbra, a aprazível paisagem da cidade, engastada na sua colina e cercada pelos férteis campos do Mondego (paisagem que o jurista evoca com laivos duma sensibilidade pré-romântica de que se encontram também toques no Reino da Estupidez ${ }^{(113)}$. Na incultura e na inércia gerais do País se enquadrava

(111) Esta ode encontra-se também no espólio de Garrett, no mesmo conjunto de papéis que pertenceram a D. Fr. Alexandre, entre alguns «Rascunhos de odes» de Ribeiro dos Santos (ms. 202-H). Não foi publicada nas Poesias de Elpino Duriense, Lisboa, 1812-1817.

(112) Vejam-se, por ex., as composições ao Doutor Ricardo Raimundo Nogueira sobre os objectos dignos da poesia e $A$ D. João José Alberto de Noronha, in Poesias de Elpino Duriense, t. I, pp. 58-62 e 26-28 respectivamente.

(1is) Confronte-se o início do C. 6. da versão $B$ do Reino da Estupidez (ed. Albuquerque, c. III, p. 101) -

«Do fértil Portugal quasi no centro

A vistosa Coimbra está fundada

Pelo cume soberbo de alto monte

$\mathrm{E}$ pelas faldas que o poente avistam,

Vai-se ao longo estendendo, até que chega

A beber do Mondego as mansas águas.

De fronte outra montanha senhoreia

A líquida corrente dividida

Da longa ponte pelos grossos arcos.

D'em torno a cercam, dando aos habitantes

Os mais belos passeios do universo,

Aprazíveis campinas, férteis vales 
a degradação da Alma Mater: terá sido talvez por duvidar da viabilidade, no marasmo colectivo, duma boa iniciativa como a da fundação da Academia das Ciências que António Ribeiro dos Santos, eleito seu sócio supranumerário em 1780, tardou em manifestar interesse pela instituição, numa atitude que

Do cristalino rio retalhados.

Da fronteira montanha que dominam

Dous famosos conventos, se desfruta

A linda perspectiva da Cidade»

- com a lisonjeira evocação da paisagem coimbrã contida na epistola *ao D.or Ricardo Raimundo Nogueira estando na Foz do Rio Douro no Porto», datada de Setembro de 1782, que se encontra, de pp. 69 a 78, no ms. 207 do espólio de Garrett, uma Collecção de autographos de $A$. Ribeiro dos Santos, Almeno e outros, que pertencera ao Bispo de Angra:
«Lá vejo a alta Coimbra: está sentada
No erguido monte; lá se está revendo
Sobre as águas do rio debruçada
E o seu Mondego, que daqui estou vendo,
No verde leito quase descoberto
As mansas águas vai adormecendo;
Os longos areais em campo aberto
Vejo alvejar ao longe, e mil esteiros,
Que os vão cortando com seu giro incerto.
De faias, olmos, chopos (sic) e salgueiros
Avisto as frescas ribas adornadas,
E verdejando ao longe altos oiteiros,
$\mathbf{E}$ as risonhas campinas dilatadas
Em qu'anda repastando o manso gado
E bandos de cornígeras manadas».

Toda esta composição está impregnada duma subjectividade pré-romântica, traduzida numa sentimentalidade que se eleva do espectáculo da natureza plácida ao pensamento de Deus e da virtude. A versão $B$ do Reino da Estupidez deixa aflorar também, apesar do registo burlesco predominante, um sentimento da natureza, sensível à cor e às formas. Veja-se, por ex., neste fragmento do início do c. III, quando se alude à digressão das Fúrias pelo Norte da Europa, uma evocação do pôr-do-sol sobre o mar:

«... meio corpo

Tingia já no pego, o meio disco

As louras comas frouxamente espalha

Pelas bordas do céu em cima d’água.

(...)

As nuvens grossas

Pedaços de ouro colhem que o sol deixa

De que formam figuras curiosas,

Que da natureza e da arte obras imitam;

Cavaleiros, estátuas, florestas,

Exércitos, armadas, torres fingem

E mil variedades que recreiam

Do espectador a viva fantasia

E disfarçam do dia as saudades». 
encontra algum eco no pouco receio que à Estupidez causa, no poema, o empreendimento do Duque de Laföes ( $\left.{ }^{114}\right)$.

Refira-se, enfim, como as preocupações puristas do autor implícito da versão $B$ do Reino da Estupidez, acusador dos «galiparlas», podem perfeitamente adequar-se ao programa linguístico de António Ribeiro dos Santos, um dos muitos que buscavam, como Filinto ou Fr. Alexandre da Sagrada Família, o autêntico e saboroso vernáculo português nos autores de Quinhentos e de Seiscentos, mostrando-se interessados também pela linguagem popular, guardiã de tanta riqueza perdida na prática fria, se não estrangeirada, dos cultos. Basta percorrer no Dicionário Bibliográfico a lista das «obras manuscritas em português» deixadas por Ribeiro dos Santos para se verificar a presença de várias consagradas a questões de língua e de poética: e leiam-se, a título de exemplo, as composiçōes dirigidas a António Ferreira de Sampaio «Sobre o estudo da Língua Portuguesa, pelo que respeita aos Prosadores» e «Sobre o estudo da Língua Portuguesa, pelo que respeita aos Poetas», incluídas no vol. I das Poesias de Elpino Duriense.

Da própria comparação da versão $A$ do Reino da Estupidez, colocada em circulação, $\operatorname{com}$ a versão $B$, que ficou oculta e só encontrei até à data testemunhada pelo ms. 198 do espólio de Garrett, parece-me resultar um último argumento favorável à autoria de Ribeiro dos Santos $\left({ }^{115}\right)$ : do texto divulgado foram retirados passos que poderiam conduzir ao seu nome pelo teor da mensagem que resultaria da sua combinação com outros, mantidos. Quem lesse a versão $A$, privada desses fragmentos reveladores, seria provavelmente levado a procurar 0 Autor entre os entusiastas do filosofismo e do regalismo estreme, o que estaria bem de acordo com a denúncia da «Viradeira» e do reitorado do Principal Mendonça contida no poema, mas se harmonizaria mal com ele, Ribeiro dos Santos, apesar da sua conflituosa relação com o Reitor.

Teria sido D. Frei Alexandre da Sagrada Família, o austero tio de Garrett que com António Ribeiro dos Santos tantas afinidades intelectuais apresenta, o depositário escolhido

(1ii) Esteves Pereira, op. cit., pp. 18-19.

(115) Devo acrescentar que alguns dos professores directamente alvejados no Reino da Estupidez, sem falar já do principal Mendonça, estiveram em relação com Ribeiro dos Santos. O Doutor Cristóvão de Almeida Soares (cf. n. 59), decano da Faculdade de Cânones, foi o padrinho de A. R. dos Santos na cerimónia do seu Doutoramento, como era, aliás, de regra. O Doutor Manuel Pedroso de Lima, tão satirizado no poema (é ele um dos oradores da sessão de homenagem universi- 
pelo canonista para guardar o «original» $\left({ }^{116}\right)$ do seu poema, que convinha rigorosamente preservar do conhecimento público? Do mútuo apreço que os uniu inequívocas provas nos restam: António Ribeiro dos Santos mandou copiar e conversar na Biblioteca Nacional, quando a dirigiu, alguns originais do Bispo de Angra, cujas obras louvou encarecidamente, tentando exortá-lo a publicá-las, quando D. Frei Alexandre, seu profundo admirador, lhe solicitou uma opinião sobre a sua validade, antes de as entregar à censura oficial que precedia a impressão. A Almeno, grande amigo de ambos, recomendava Ribeiro dos Santos, a propósito do Prelado:

\author{
aLouva com versos dignos d'alta fama \\ Seu grande coração, sua alma grande, \\ Seu ânimo tenaz na tenção recta; \\ Mostra, como defende firme a estância, \\ Em que os Céus o puseram; como inteiro \\ C'o sublime poder das santas chaves, \\ Sem se dobrar a preço, a força, a medo, \\ Seguindo vai intrépido à direita \\ Vereda da virtude e da verdade, \\ Tudo o mais baixo tendo por desonra.» $\left({ }^{117}\right)$
}

D. Frei Alexandre reuniu, por sua vez, numerosos textos do amigo, alguns ligados aos conflitos universitários em que se envolveu ( $\left.{ }^{118}\right)$.

tária à Estupidez, cf. n. 69), esteve envolvido na questão que opôs Ribeiro dos Santos ao Principal Mendonça a propósito da obrigatoriedade da «subscrição» das teses de «Conclusões Magnas» pelo seu Presidente, antes da sua sujeição aos lentes censores. Pedroso de Lima sustentava, de acordo com o Reitor e com o seu colega António Henriques da Silveira, o ponto de vista contrário ao de Ribeiro dos Santos. Cf. Esteves Pereira, op. cit., pp. 21 e segs., em particular p. 22, n. 1.

${ }^{\left({ }^{16}\right)}$ Se o texto do ms. 198 for da autoria de Ribeiro dos Santos, não creio, todavia, que seja da sua mão, mas sim da dum dos copistas que trabalhava frequentemente para ele - o mesmo, por exemplo, que terá ou copiado, ou escrito sob ditado seu, os Rascunhos de odes citados na n. 111.

(1ir) «A Almeno na vinda de Silvio», in Poesias de Elpino Duriense, t. I, 1812, p. 143.

(118) Dos textos de D. Frei Alexandre reunidos e mandados copiar por Ribeiro dos Santos pode ver-se uma relação no Catálogo metódico dos manuscritos de composição alheia que o Dr. António Ribeiro dos Santos doou, em sua vida, à Real Biblioteca da Corte, publicado por L. F. de Carvalho Dias em «Inéditos de António Ribeiro dos Santos» (Boletim da Universidade de Coimbra, vol. XXXIII, 1977, p. 164). As cartas do Bispo de Angra a A. R. dos Santos sobre a eventual publicação das suas obras podem ler-se em Ofélia Paiva Monteiro, D. Frei Alexandre da Sagrada Família. A sua espiritualidade e a sua poética, 
Serão estes argumentos bastantes para julgar António Ribeiro dos Santos o autor do Reino da Estupidez? Esperemos que novos dados venham confirmar ou infirmar as hipóteses que aqui ficam consignadas $\left({ }^{110}\right)$.

pp. 31-34. Do vultuoso número de textos de A. Ribeiro dos Santos reunidos por $\mathrm{D}$. Frei Alexandre dá clara ideia o Inventário do espólio de Almeida Garrett citado na n. 1 Nesse número se encontram (ms. 202-A) documentos relativos ao conflito do Canonista com o Principal Mendonça sobre a questão da subscrição das teses de Conclusões Magnas. (110) Uma palavra de agradecimento é devida, por valiosos auxílios que me prestaram para a realização deste trabalho, à Senhora D. Maria Luísa Lemos, bibliotecária da B.G.U.C., ao Sr. Doutor José Esteves Pereira e aos Sr." Dr."* João Pereira Gomes, Rosa Maria Esteves, Isabel Maria Vargues e José Oliveira Barata. 